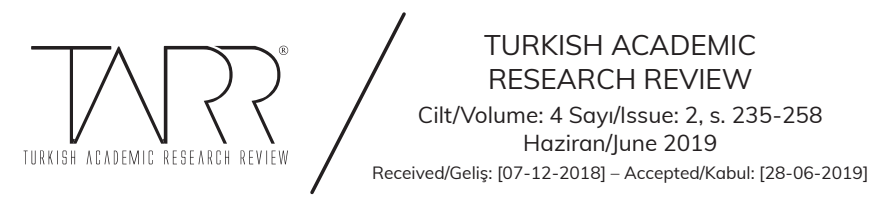

\title{
Anonim Şirketlerde Sorumluluk Davası Açılmasında Genel Kurul Kararı Alınmasının Gerekli Olup Olmadığı Üzerine Bir Değerlendirme $^{1}$
}

Sevda Bora Çınar²

\section{Özet}

Eski 6762 sayılı Türk Ticaret Kanunu (ETTK) anonim şirket adına yönetim kurulu üyelerine karşı sorumluluk davası açılması için genel kurul tarafından davanın açılmasına yönelik bir karar alınmasını zorunlu tutmaktaydı. Yargıtay da genel kurul kararı alınmaması halinde bu durumu dava şartı eksikliği olarak kabul etmekteydi. Bu sebeple de kararın alınmasına kadar bu durumu tamamlanabilir bir eksiklik olarak değerlendirmekte ve davayı bu sebeple ertelemekteydi.

6102 sayılı Türk Ticaret Kanunu (TTK) ise şirketin, yönetim kurulu üyelerine karşı açacağı sorumluluk davasını açıkça genel kurul kararı alınması şartına bağlamamıştır. Ancak TTK m. 479/3-c hükmünde, ibra ve sorumluluk davası açılmasına ilişkin genel kurul kararlarında pay sahiplerinin oyda imtiyaz hakkının geçerli olmayacağı belirtilmiştir. Bu hüküm ise sorumluluk davası açılmasına ilişkin bir genel kurul kararını ortaya koymaktadır ki bu hüküm doktrinde ciddi tartışmalara sebebiyet vermiştir. Doktrinde, ETTK uygulamasının aynen devam ettiğini ileri süren görüşler bulunduğu gibi TTK m. 479/3-c hükmünün unutularak kanunda bırakıldığını ileri süren görüşler de bulunmaktadır.

Yargitay, ETTK uygulamasını aynen devam ettirmek şeklinde, doktrinde ortaya atılan ilk görüşü benimsemiştir. Ancak kanunda açıkça dava şartı olarak düzenlenmemiş bir durumun, bu şekilde yorum yoluyla dava şartı haline getirilmesi şirketin hak arama özgürlüğünü geçici de olsa ihlal etmektedir. Ayrıca yorum yoluyla oluşan uygulamanın Avrupa İnsan Hakları Sözleşmesi (AİHS) m. 6 hükmünde düzenlenen hak arama özgürlüğünün ihlali sonucunu doğurabileceği de gözden kaçırılmamalıdır.

Anahtar Kelimeler: Anonim Şirket, Genel Kurul Kararı, Dava Şartı, Sorumluluk Davasi.

1 Bu çalışma 12-14 Ekim 2018 tarihinde düzenlenen Türk Akademik Araştırmalar Dergisi Uluslararası Multidisipliner Kongresinde (Turkish Academic Research Review International Multidisciplinary Congress-TARRC) sunulan "Anonim Şirketlerde Sorumluluk Davası Açılmasında Genel Kurul Kararı Alınması: Dava Şartı mı? Unutulmuş Bir Hüküm mü?” adlı bildirinin genişletilmiş halidir.

2 Akdeniz Üniversitesi Hukuk Fakültesi, Ticaret Hukuku ABD, av. sevdabora@gmail. com 


\title{
An Evaluation on Whether Required Taking The Decision of The General Assembly to Open A Case of Liability İn Joint Stock Companies
}

\begin{abstract}
The Former Turkish Commercial Code No. 6762 (FTCC) required a general assembly resolution to file a lawsuit against the members of the board of directors. If the decision of the general assembly was not taken, this was considered as a deficiency in the procedural prerequisities by the Supreme Court. For this reason, the Supreme Court, evaluating that this deficiency can be completed, postponed the case until the decision was taken.
\end{abstract}

Turkish Commercial Code No. 6102 (TCC) has not explicitly regulated the necessity of taking the decision by the general assembly to file a lawsuit against the members of the board of directors. However, in the TCCArticle 479/3-c, it isstated that shareholders' voting rights are not valid in the decisions of the general assembly regarding the release and liability case. This provision lays down a decision of the General Assembly regarding the opening of a liability case, which has caused serious controversy in the doctrine. In the doctrine, there are opinions suggesting that the implementation of the FTCC continues in the same way. There are also opinions suggesting that the provision of $479 / 3-\mathrm{c}$ has been forgotten and left in the law.

The Supreme Court adopted the first opinion put forward in the doctrine by continuing its former practice. However, making a case not explicitly regulated by law as a procedural prerequisities in such a way, violates the company's freedom of claim, even temporarily. Moreover, it should not be overlooked that this practice formed through interpretation could lead to a violation of the right to legal remedies regulated by European Convention of Human Rights (ECHR) article 6.

Keywords: Joint Stock Company, The Decion of General Assembly, Procedural Prerequisities, Liability Case.

\section{Giriş}

Yönetim kurulu üyeleri ve yönetimin devredildiği hallerde yönetimle görevli üçüncü kişiler, görevlerini tedbirli bir yöneticinin özeniyle yerine getirmek ve şirketin menfaatlerini dürüstlük kurallarına uyarak gözetmek yükümlülügüu altındadır (TTK m. 369). Nitekim yönetim kurulu üyelerinin şirkete karşı olan bağl1lık borcunun bir gereği olarak, menfaat çatışması halinde, kendilerinin, şirketteki çoğunluk hissedarların, onların yakını olan kişilerin ya da üçüncü kişilerin menfaatleri yerine, şirketin menfaatini üstün tutmamakla da yükümlüdür ${ }^{3}$. Ted-

3 Tekinalp, Ünal, Sermaye Ortaklıklarının Yeni Hukuku, Değișiklikler ve İkincil Düzenlemelerle Güncelleștirilmiş 4. Bası, İstanbul: Vedat Kitapçılık, 2015, N. 12-119; Helvacı, Mehmet, "Anonim Ortaklık Tarafından Yönetim Kurulu Üyelerine Karşı Açılacak Sorumluluk Davalarında Genel Kurul Kararının Gerekli Olup Olmadığ 1 Sorunu -Düșünceler ve Değerlendirmeler-”, Yürürlüğünün 5. Yılında ve Yargıtay Kararları

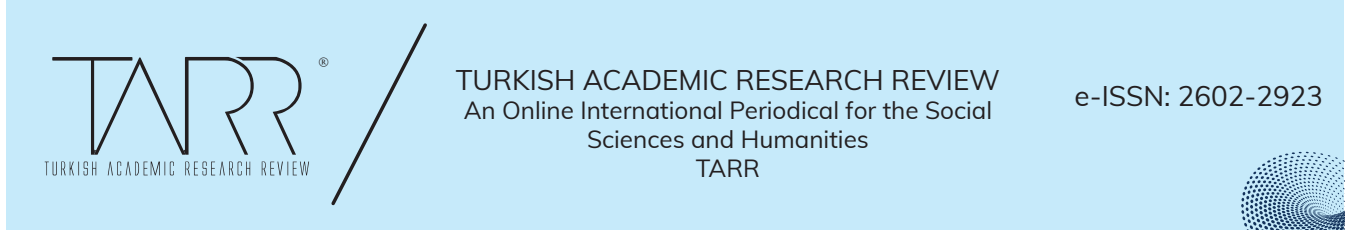


birli bir yöneticinin özeniyle ve şirket menfaatlerini gözeterek görevini yerine getirmek zorunda olan yönetim kurulu üyeleri ile yönetimde görevli olan diğer kişiler, bu yükümlülüklerini kusurlarıyla ihlâl ettikleri takdirde ise hem şirkete hem pay sahiplerine ve hem de şirket alacaklılarına karşı verdikleri zarardan sorumlu tutulmuştur (TTK m. 553/1).

Şirket zararının talep edilmesine ilişkin TTK, ETTK'nın aksine şirket zararını talep edebilecek kişiler ve şartları açısından kapsamlı değişiklikler yapmıştır. Bu değişikliklerden biri de şirket zararlarının talep edilmesinin, genel kurulda bu yönde bir karar alınması şartına bağlanmamasıdır. Ancak genel kurulda oyda imtiyazın geçerli olmadığı kararları düzenleyen TTK m. 479/3-c hükmünde sorumluluk davası açılması kararının da belirtilmiş olması, sorumluluk düzenlemelerinde yer almayan genel kurul kararı alınması şartının yeni sistemde de gerekli olup olmadığı noktasında tereddütler yaratmış ve bu konu doktrinde de çeşitli görüşler ortaya atılmasına yol açmıştır.

Çalışmamızda öncelikle doktrindeki görüşler açıklanacak, sonrasında uygulamadaki durumu görmek adına çeşitli Yargitay kararlarına yer verilerek Yargitay'ın soruna ilişkin yaklaşımı incelenecektir. Doktrindeki görüssler ve Yargıtay kararlarının incelenmesinden sonra ETTK ve TTK'nın sorumluluğa ilişkin getirdikleri sistemin karşılaştırmalı olarak incelenmesi neticesinde, TTK'nın şirket zararlarının talebinde genel kurul kararını zorunlu olarak düzenleyip düzenlemediğine ilişkin değerlendirme ve görüşlerimize yer verilecektir. Son olarak da uygulama ve doktrindeki tartışmalı duruma son verebilecek çözüm önerilerimizle çalışmamız tamamlanacaktır.

\section{Genel Kurul Kararının Gerekli Olup Olmadığına İlişkin Doktrindeki Görüşler}

ETTK'dan farklı olarak, TTK m. 555 hükmünde, şirketin yönetim kurulu üyelerine karşı açacağı sorumluluk davası için genel kurul kararının gerekli olduğuna ilişkin açık bir düzenleme bulunmamaktadır. Ancak belirttiğimiz gibi oyda imtiyazın geçerli olmadığı genel kurul kararlarından biri olarak, TTK m. 479/3-c hükmünde sorumluluk davası açılması kararı da yer almaktadır. Bu durum ise doktrinde konuya ilişkin çeşitli görüşler ortaya atılmasına sebebiyet vermiştir. Bu görüşleri temel olarak üç grup halinde incelemek mümkündür.

Işığında Türk Ticaret Kanunu Sempozyumu (20 Ekim 2017), İstanbul: On iki Levha Yayıncilık, 2018, s. 158 vd. ; Pulaşlı, Hasan. Şirketler Hukuku Genel Esaslar, Gözden Geçirilmiş, 6728 Sayılı Kanunla Getirilen Yenilikler ve Yapılan Değişiklikler İşlenmiş, Güncellenmiş ve Genişletilmiş 5. Baskı, Ankara: Adalet Yayınevi, 2017, N. 20-226; Akdağ Güney, Necla, Anonim Şirket Yönetim Kurulu. İstanbul: Vedat Kitapçılık, 2012, s. 135 vd. ; Yanlı, Veliye/ Akın, Murat Yusuf, Yeni Türk Ticaret Kanunu Dünya Değişiyor. Ya Siz?, 2. Bask1, İstanbul: KPMG, 2012, s. 55; Cahn, Andreas/Donald, David C. , Comparative Company Law, Newyork: Cambridge University Press, 2010, s. 333.

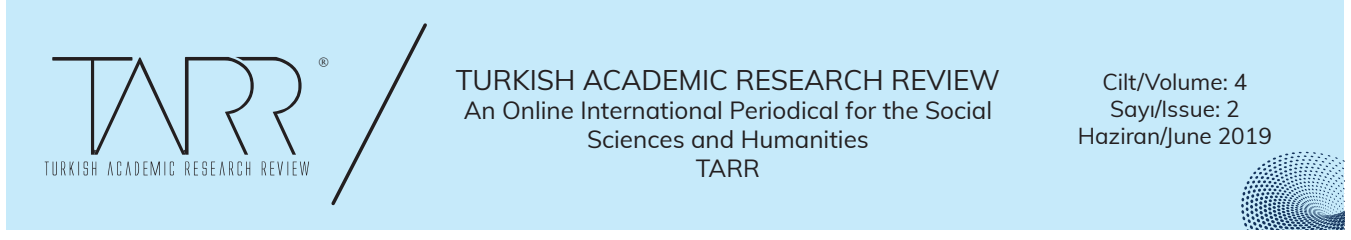




\section{A. Genel Kurul Kararının Gerekli Olduğu Görüşü ve Bu Görüşün Değerlendirilmesi}

İlk görüş, sorumluluk davasında genel kurul kararının gerekli olduğunu savunmaktadır. Bu görüşe göre her ne kadar açıkça genel kurul kararı alınması gerektiği TTK m. 553 ve devamı hükümlerinde düzenlenmemiş olsa da TTK m. 479/3-c hükmünde sorumluluk davası açılması kararında oyda imtiyazın geçerli olmadığı düzenlemesiyle, genel kurulda sorumluluk davası açılmasına yönelik bir karar alınması gerektiği sonucuna ulaşılabilmektedir ${ }^{4}$. Ayrıca bu görüşün taraftar bulma sebebinin bir diğerini de finansal tablolara, yönetim kurulunun y1llık raporuna, yıllık kâr üzerinde tasarrufa, kâr payları ile kazanç paylarının belirlenmesine, yedek akçenin sermayeye veya dağıtılacak kâra katılması dâhil, kullanılmasına dair kararların alınmasının genel kurulun devredilemez görev ve yetkileri arasında sayılması oluşturmaktadır (TTK m. 408/2-d). Genel kurulun bu yetki ve görevleri göz önüne alındığında, yönetim faaliyetlerinin sonucunu değerlendirecek organ genel kurul olduğundan, sorumluluğun değerlendirmesinin de yine genel kurul tarafından yapılacağı sonucuna ulaşılması gerektiği ileri sürülmektedir ${ }^{5}$.

$\mathrm{Bu}$ görüsse göre her ne kadar sorumluluk davası açılmasına karar verecek organın genel kurul olduğu ileri sürülse de davada şirketi yine yönetim kurulunun temsil edeceği kabul edilmektedir. Bu sebeple de yönetim kuruluna karşı açılan sorumluluk davasında menfaat çatışmasının önüne geçilmesi amacıyla, şirketin kayyım tarafından temsili gerekecektir. Ayrıca sorumluluk davası açılmasına karar veren genel kurul ile yönetim kurulunun arasındaki güven ilişkisi zedeleneceğinden, aynı toplantıda mevcut yönetim kurulunun azli ve yenisinin oluşturulması da imkân dahilindedir. Bu durumda kayyım atanmasına gerek olmaksızın, şirketle arasında herhangi bir menfaat çatışması bulunmayan yeni yönetim kurulunun, davayı açmasında da bir sakınca bulunmayacaktır ${ }^{6}$.

Bu görüşün temel dayanak noktası sorumluluk davası açma kararının genel kurul tarafından alınması gerektiğinin, TTK m. 479/3-c hükmünde dolaylı olarak da olsa öngörülmesidir. Nitekim genel kurul ve yönetim kurulunun yetki kapsam1nın ve sınırlarının tespitine ilişkin hükümler değerlendirildiğinde, TTK m. 408/1 hükmü uyarınca genel kurul, kanunda ve esas sözleşmede açıkça öngörülmüş bulunan hâllerde karar mercii olarak belirlenmiştir. TTK m. 374 hükmünde de yönetim kurulu, kanun ya da esas sözleşme uyarınca genel kurulun yetkisinde

4 Bu görüşte bkz. Kendigelen, Abuzer, Yeni Türk Ticaret Kanunu: Değişiklikler, Yenilikler ve İlk Tespitler. Güncellenmiş 2. Basıdan 3. (Tipkı) Bası, İstanbul: On İki Levha Yayıncılık, 2016, s. 308, dn. 164; Şener, Oruç Hami, Ortaklıklar Hukuku. Gözden Geçirilmiş 2. Bası, Ankara: Seçkin Yayıncılık, 2015, s. 418; Bahtiyar, Mehmet, "Anonim Şirket Adına Yönetim Kurulu Üyelerine Karşı Açılacak Sorumluluk Davasında Genel Kurul Kararının Gerekli Olup Olmadığı Sorunu”, Prof. Dr. Seza Reisoğlu Armağanı, Ankara: Bankacılık Enstitü Yayınları, 2016, s. 405-413; Bahtiyar, Mehmet, Ortaklıklar Hukuku, Güncellenmiş 12. Bası, İstanbul: Beta, 2017, s. 399, dn. 692; Bilgili, Fatih/ Demirkapı, Ertan, Şirketler Hukuku, 9. Baskı, Bursa: Dora, 2013, s. 261, dn. 289; Limited şirketler açısından olmakla birlikte aynı gerekçelerle aynı sonuca ulaşan görüş için bkz. Yıldız, Şükrü, "Limited Ortaklıklarda Müdürlerin Sorumluluğu”, İstanbul Ticaret Üniversitesi Sosyal Bilimler Dergisi, C. 12, S. 24, 2013/2, s. 77 vd.

5 Üçışık, Güzin/ Çelik, Aydın, Anonim Ortaklıklar Hukuku, C. 1, Ankara: Adalet Yayınları, 2013, s. 549 vd. ; Altay, Sttkı Anlam, Anonim Ortaklıkta Yönetim Yetkilerinin Devrinin Sorumluluğa Etkileri, İstanbul: Vedat Kitapçıllk, 2011, s. 236.

6 Şener, s. 418.

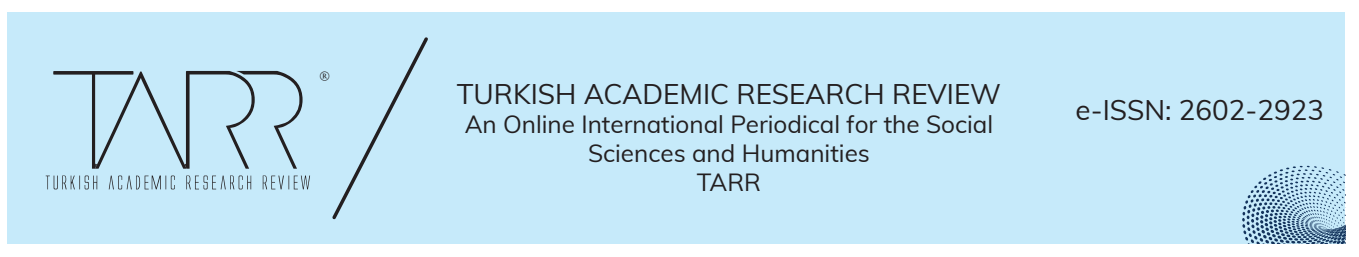


bırakılmış bulunanlar dışında, şirketin işletme konusunun gerçekleştirilmesi için gerekli olan her çeşit iş ve işlemler hakkında karar almaya yetkili kılınmıştır. Kanunun lafzi olarak yorumlanması halinde, kanunda genel kurulun sorumluluk davası açılması kararı almasına ilişkin TTK m. 479/3-c hükmünün varlığı karşısında, yönetim kurulunun dava açmaya ilişkin bir karar alma yetkisinin bulunmadığ sonucu ortaya çıkabilmektedir ${ }^{7}$. Ancak aynı zamanda sorumluluk düzenlemelerinde sorumluluk davası açılması kararının genel kurula özgülendiğini belirten açık bir hüküm olmadığı gibi davanın "şirket" tarafından açılacağı belirtilmiştir. Şirket adına hareket edecek organın yönetim kurulu olması karşısında, yönetim kurulunun dava açmasını engelleyen bir düzenleme de bulunmamaktır. Ayrıca kanaatimizce TTK m. 374 hükmündeki genel kurulun yetkisinde bırakılmış kararlar ifadesinin, genel kurulun devredilemez görev ve yetkileri kapsamında olanlar şeklinde anlaşılması gerekmektedir ${ }^{8}$.

\section{B. Genel Kurul Kararının Gerekli Olmadığı Görüşü ve Bu Görüşün Değerlendirilmesi}

İkinci görüş ise ETTK'da açıkça düzenlenmiş dava şartı niteliğindeki genel kurul kararı alınması gerekliliğine TTK'da da aynı şekilde açıkça yer verilmesinin gerektiğinden hareketle, bilinçli olarak eski düzenlemeden vazgeçildiğini ve TTK m. 479/3-c hükmünün ise unutulduğu için o şekilde kanunda bırakıldığını ileri sürmektedir ${ }^{9}$. Ayrıca TTK m. 479/3-c ile getirilen genel kurul kararı alınmasına yönelik dolaylı bir hükmün ETTK uygulamasında olduğu gibi genel kurul kararı alınmasını dava şartı niteliğine getiremeyeceği ileri sürülmektedir ${ }^{10}$.

$\mathrm{Bu}$ görüşe göre, dava açma yetkisi genel kurul kararı gerekmeksizin yönetim kurulundadır ${ }^{11}$. Davanın görevdeki yönetim kurulu üyelerine karşı açılması halinde, davacı ve davalı sıfatlarının fiziken birleşmesi sebebiyle menfaat çatışması ortaya çıkacağından, şirketi temsilen kayyım tarafından davanın açılabileceği önerisi sunulmaktadır ${ }^{12}$. Ayrıca genel kurulun ya da yönetim kurulunun davayı açması için vekil tayin edilmesini isteme imkânı olduğu gibi genel kurulun, sorumluluğu

7 Yönetim kurulu üyelerine karşı sorumluluk davası açılması kararının genel kurulun devredilemez görev ve yetkileri kapsamında olduğuna ilişkin görüş için bkz. Tekinalp, N. 13-11.

8 Aynı şekilde maddenin genel kurulun münhasır yetkisinde şeklinde değiştirilmesi gerektiği yönündeki önerisi için bkz. Moroğlu, Erdoğan, 6102 saynl Türk Ticaret Kanunu Değerlendirme ve Öneriler, 7. Bask1, İstanbul: On İki Levha Yayıncılık, 2012, s. 168; Benzer değerlendirme için bkz. Helvacı, Sempozyum I, s. 158.

9 Poroy, Reha/ Tekinalp, Ünal/ Çamoğlu, Ersin, Ortaklıklar Hukuku I, Yeniden yazılmış 13. Bası, İstanbul: Vedat Kitapçılık, 2014, N. 601-603.

10 Genel kurul kararı alınmasının davanın dinlenebilme şartı olmadığı yönünde bkz. Tekinalp, N. 16-92; Akdağ Güney, s. 218 vd.

11 Pulaşlı, Genel Esaslar, N. 32-137; Karahan, Sami (Ed.), Şirketler Hukuku, Konya: Mimoza Yayıncılık, 2012, s. 799.

12 Tekinalp, N. 16-92; Karahan/Doğrusöz Koşut, s. 799; Bilgili/Demirkapı, s. 596; Bu hallerde davayı her bir pay sahibinin açabileceğinden hareketle sorunun çözüleceği yönünde bkz. Pulaşlı, Genel Esaslar, N. 32-138, N. 67a; ETTK döneminde bu gibi hallerde denetçilere tanınan sorumluluk davası açma imkanıyla çözüme ulaşıldığı ancak denetçilerin organ olmaktan çıkarılması ile birlikte bu imkanın muadili bir çözüme yer verilmediğine yönelik görüşiçin bkz. Yasaman, Hamdi, "Yönetim Kurulu Üyelerine Karş1 Açılabilecek Sorumluluk Davaları”, Prof. Dr. Oğuz İmregün'e Saygı Sempozyumu (Galatasaray Üniversitesi Hukuk Fakültesi Dergisi), 2013/2, s. 106.

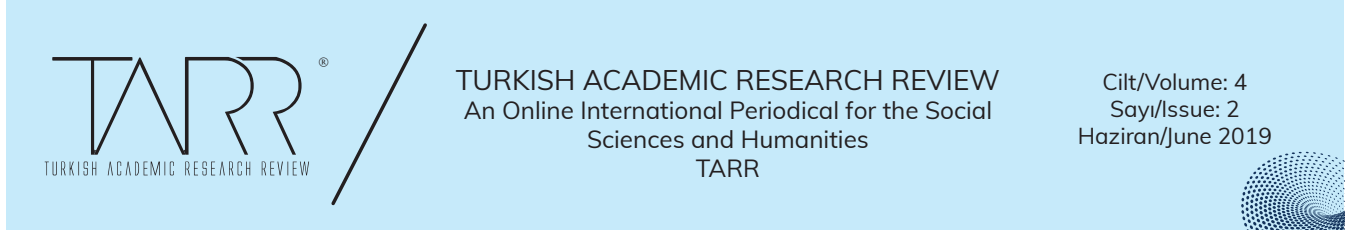


istenen yönetim kurulunu görevden alarak yenilerini seçmesi neticesinde, davay1 yeni seçilen yönetim kurulunun açması da mümkündür ${ }^{13}$.

Sorumluluk davası açılması kararının yönetim kurulunca alınması gerektiğinin bir diğer sebebi de yönetim kurulunun, yönetimle görevli kişilerin kanunlara, esas sözleşmeye, iç yönergelere ve yazılı talimatlara uygun davranıp davranmadığının üst gözetimiyle de sorumlu tutulmuş olmasıdır (TTK m. 375/1-e). Bu üst gözetim görev ve yetkisinin TTK'da devredilemez olarak düzenlenmesi karşısında, bu görevin yerine getirilmesi neticesinde sorumlular hakkında gerekli sorumluluk davalarının açılması da bu gözetim görevinin ayrılmaz bir parçası olarak düşünülebilir. Bu durumda da şirketin üst gözetimi görevinin yerine getirilmesini sağlayıcı en önemli enstrümanlardan biri olan sorumluluk davası açılması yetkisinin de yönetim kurulunda olduğunu kabul etmek gerekir. Ancak genel kurulda oyda imtiyaz hakkının geçerli olmadığı kararlar arasında sorumluluk davasının da sayılmıs olmasının elbette ki hukuki bir etkisi olmak zorundadır. Bu hükmün unutularak kanunda bırakılması ya da bilinçli olarak TTK'da yer alması arasında etkisi bakımından hiçbir fark bulunmamaktadır. Kaldı ki limited şirketler açısından oy hakkı ve hesaplanması başlıklı TTK m. 618/3-c hükmünde oy hakkının esas sermaye paylarının sayısına göre belirlenmesine ilişkin şirket sözleşmesi hükmünün sorumluluk davası açılması hakkında karar verilmesi halinde uygulanmayacağ 1 düzenlenmiş ve TTK m. 479/3-c hükmüne benzer bir düzenleme limited şirketler hakkında da öngörülmüsstür. Bu durum da TTK m. 479/3-c hükmünün unutulduğu savını kanaatimizce devre dışı bırakmaktadır ${ }^{14}$.

\section{Duruma Göre Değerlendirme Yapılması Gerektiği Görüşü ve Bu Görüşün Değerlendirilmesi}

Son görüş ise sorumluluk davası açma yetkisinin yönetim kurulunda olduğunu, ancak TTK m. 479/3-c hükmü de göz önüne alındığında, genel kurulun da sorumluluk davası açılmasına karar verebileceğini savunmaktadır ${ }^{15}$. Bu görüşe göre yönetim kurulu tarafından sorumluluk davası açılması kararının alınamadığ durumlarda, genel kurul kararı alınması yoluyla da dava açılması mümkün hale gelecektir ${ }^{16}$. Genel kurulun sorumluluk davası açılmasına ilişkin kararı ise bir izinden ziyade dava açılması gerektiğine yönelik bir irade olarak değerlendirilmelidir $^{17}$.

13 Akdağ Güney, s. 218-222.

14 Aynı yönde bkz. Bahtiyar, Armağan, s. 410; Arslan, İbrahim/ Tüzemen Atik, Ebru, "Anonim Şirketlerde Yönetim Kurulu Aleyhine Sorumluluk Davası Açılması Kararı ve Açılacak Davada Şirketin Temsili”, Başkent Üniversitesi Hukuk Fakültesi Dergisi, C. 2, S. 2, 2016, s. 20 vd.

15 Helvac1, Sempozyum I, s. 149; Helvac1, Sempozyum II, s. 354.

16 Bilgili/Demirkapı, s. 596; Kortunay, Ayhan, 6102 Saynl Türk Ticaret Kanununa Göre Anonim Şirketlerde Yönetim Kurulu ve Üyelerin Bilgi Edinme Hakkı, İstanbul: On İki Levha Yayınc1lı, 2015, s. 266; Limited şirketler açısından değerlendirilmekle birlikte benzer görüşte bkz. Yıldırım, Ali Haydar, Türk Ticaret Kanunu Tasarısı'na Göre Limited Ortaklık Müdürünün Hukuki Durumu, İzmir: Güncel Hukuk Yayınları, 2008, s. 167.

17 Pulaşl1, Genel Esaslar, N. 32-139, dn. 124a ve N. 26-56, dn. 54a; Helvacı, Sempozyum I, s. 170.

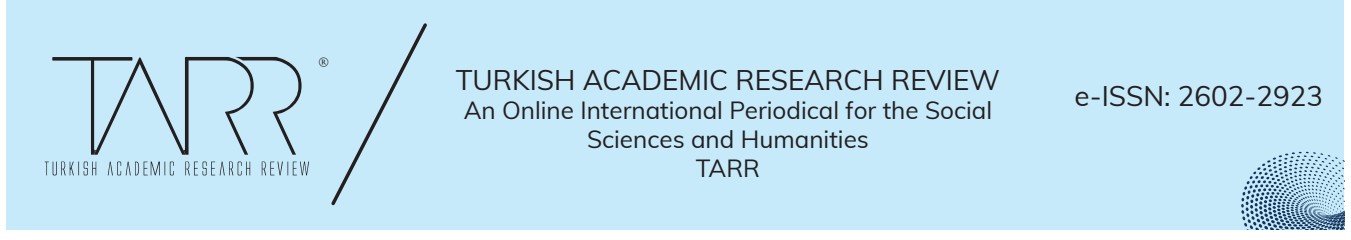


Genel kurulda sorumluluk davası açılması yönünde bir karar alınması üzerine de yönetim kurulu ya davayı açacaktır ya da alınan kararın iptalini talep edecektir. Aksi halde genel kurul kararlarını yerine getirmeyen yönetim kurulu için bu durum, kanaatimizce gündemde madde olmasa bile yönetim kurulu üyelerinin azli ve yenilerinin seçilmesi için bir haklı neden teşkil edecektir. Ayrıca sorumluluk davası açılması kararını uygulamayan yönetim kurulu üyelerinin bu durumdan kaynaklanan şirket zararlarını da ayrıca tazmin etmeleri gerekecektir ${ }^{18}$. Nitekim genel kurul kararlarını uygulamaya geçirmekle görevli organ yönetim kuruludur ve bu kararların uygulanmamasından da ayrıca sorumluluğu doğacaktır. Bu sonuç ETTK m. 336/4 hükmünde açıkça düzenlenmiş olmasına rağmen benzer bir sorumluluk hükmüne TTK'da ayrıca yer verilmemekle birlikte, TTK m. 375/1-f hükmünde yönetim kurulunun görevleri arasında genel kurul kararlarının yürütülmesi de yer aldığından aynı sonuç TTK açısından da geçerlidir.

\section{Genel Kurul Kararının Gerekli Olup Olmadığına İlişkin Yargitay'ın Tutumu}

ETTK döneminde, sorumluluk davası açılmasında genel kurul kararının alınmış olması, davanın dinlenilme şartlarından sayılmış ve bu yönde bir genel kurul kararı alınmaksızın açılan davanın reddedilmesi gerektiği Yargıtay tarafından benimsenmişti ${ }^{19}$. Sonradan şirket tarafından icazet verilmesi dahi davanın dinlenilme şartını yerine getirmemekteydi. Ancak sonrasında Yargitay bu katı tutumunu değiştirmiş ve genel kurul kararı alınmasını, süre verilerek düzeltilebilecek bir eksiklik olarak değerlendirerek, kararın alınmasıyla davaya devam edilebileceği fikrini benimsemiștir ${ }^{20}$.

TTK döneminde her ne kadar açıkça genel kurul kararı ile dava açılabileceği yönünde bir düzenleme bulunmasa da Yargıtay, doktrinde ortaya atılan ve yukarıda açılanan ilk görüşü benimseyerek eski uygulamasını devam ettirmektedir. ETTK döneminde olduğu gibi Yargıtay'ın tutumu, genel kurul kararı alınmamış olmasını bir dava şartı eksikliği olarak değerlendirmek şeklinde gelişim göstermiştir. Yine aynı uygulama limited şirketler için de geliştirilmiş ve TTK m. 618/3-c hükmü dayanak gösterilerek sorumluluk davası açılmasında ortaklar kurulu kararı

18 Aynı yönde bkz. Çamoğlu (Poroy/Tekinalp), Ortaklkklar ve Kooperatif Hukuku, N. 596.

19 Bu tutumun katı bir yaklaşım olduğu yönünde bkz. Helvacı, Sempozyum I, s. 143.

20 Örnek bir Yargitay kararının ilgili kısmı şu şekildedir: "1163 sayıl Kooperatifler Kanununun 98. maddesinin yaptiğı yollama nedeniyle olayda uygulanması gereken Türk Ticaret Kanununun 341. maddesi uyarınca, yöneticiler hakkında dava açılabilmesi, kooperatif genel kurulunca bu konuda karar alınmasına ve davanın da kooperatif denetçileri tarafından açılmasına bağhdır. Dosyada, bu konuda alınmış bir genel kurul kararı mevcut olmadığı gibi, davanın da denetçiler tarafından açılmadığı anlaşılmaktadır.

Bu durumda mahkemece, HUMK. nun 39 ve 40. maddeleri uyarnca, bu konuda varsa genel kurul kararnı ibraz ettirmek ve ayrıca, açılmış işbu davaya denetçilerin muvafakatın sağlamak için davacı vekiline yeterli süre vermek ve belirtilen bu eksikliklerin ikmalinden sonra yöneticiler hakkındaki davaya da devam olunmak; aksi halde, yönetim kurulu üyeleri olan davalılar hakkındaki davanın reddine karar verilerek, sadece yüklenici ile olan davayı esastan sonuçlandırmak gerekirken, haklarında dava şartı oluşmayan yöneticiler yönünden de esastan hüküm tesisi doğru olmamıs ve kararın bu nedenle bozulması gerekmiştir." Y. 15. HD, T. 27. 2. 1997, E. 1996/5998, K. 1997/1111, http: //www. hukuki. net/ictihat/Yargitay_15_Hukuk_Dairesi_1996-5998. php (Erişim Tarihi: 07. 12. 2018).

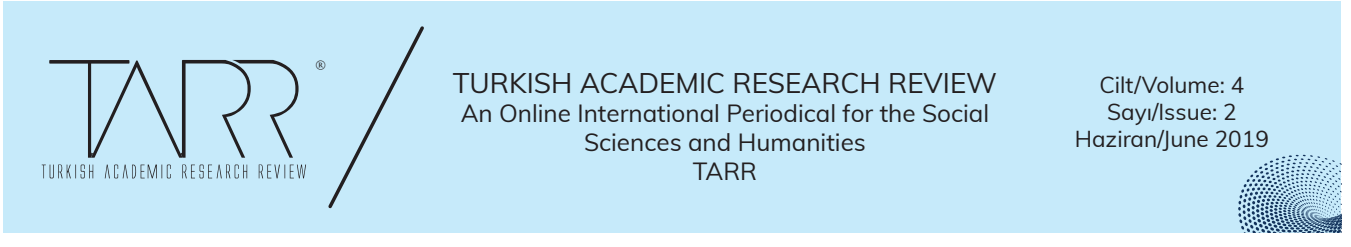


alınması gerekli görülmüştür ${ }^{21}$. Ancak bu dava şartının yokluğu davanın hemen usulden reddi sonucunu doğurmamakta; ETTK döneminde olduğu gibi şirkete eksikliği gidermesi için süre verilerek bu süre içerisinde eksiklik giderilmediği takdirde davanın reddedilmesi yolu benimsenmektedir ${ }^{22}$. Bu çözüm yolu vekalet yetkisi olmaksızın bir kişinin dava açması halinde davacı gösterilen kişiye onay (vekalet) vermesi için süre tanınması imkânı gibi değerlendirilebilir. Nitekim böyle bir durumda onay verilerek giderilmesi mümkün bir dava şartı eksikliği söz konusu olduğundan, mahkeme onay verebilecek kişiye süre vermeli ve bu süre içerisinde onay verilmezse davayı usulden reddetmelidir ${ }^{23}$. Aynı şekilde HMK m. 115/2 hükmünde de mahkemenin, dava şartı eksikliğini tespit etmesi halinde, davanın usulden reddine karar vereceği, ancak dava şartı eksikliğinin giderilmesi mümkün olduğunda ise bunun tamamlanması için ilgili kişiye kesin süre vereceği düzenlenmiştir. Bu süre içinde dava şartı eksikliği giderilmemişse de mahkeme, davayı, dava şartının sağlanamaması sebebiyle usulden reddedecektir.

21 Yargıtay kararının ilgili kısmı şu şekildedir: “Mülga 6762 sayıl TTK’nın 556. maddesinde şirket yöneticilerinin sorumlulukları hakkında anonim șirketin bu hususlara ilişkin hükümlerinin uygulanacağı öngörülmüş olup, bu yollama ile uyuşmazhı̆a aynı Yasa'nın 341. maddesi uygulanacaktır. Bu maddeye göre sorumluluk davasının açılabilmesi için, bu yönde alınmış bir ortaklar kurulu kararı bulunması gerekmekte olup bu husus dava şartıdır. Dava tarihinde yürürlükte bulunan 6102 sayıl Türk Ticaret Kanunu uygulaması da ayn yöndedir. (m. 618/ son) Dava konusu olayda sorumluluk davası açılması için alınmış bir genel kurulu kararı bulunmadığından dava açma koşulu oluşmamış ise de bu husus yargılama sırasında tamamlanabilir. Bu durumda mahkemece genel kurul tarafından bu yönde bir karar alınması için davacı tarafa mehil ve gerektiğinde kesin mehil verildikten sonra sonucuna göre bir hüküm tesisi gerekirken ...” Y. 11. HD, 26. 02. 2015, E. 2015/1754, K. 2015/2626, https: //www. kararara. com (Erişim Tarihi: 17. 09. 2018).

22 Bu yöndeki kararların ilgili kısmı şu şekildedir: “... yargılama sırasında yürürlüğe giren 6102 sayıl TTK hükümleri arasında mülga TKK'nın 341. maddesi gibi açık bir düzenleme olmamakla birlikte 6102 sayılı TTK'nın 408/1 ve 479/3-a maddelerindeki düzenleme karşısında anonim șirket yöneticileri hakkında sorumluluk davası açılabilmesi için, şirket genel kurulunda karar alınması gereklidir. Fakat, anılan yönteme uyulmaması davanın hemen reddi sonucunu doğurmamalıdır. Somut olayda dava, şirket yöneticisi . . . tarafindan şirketi temsilen verilen vekaletname ile açılmış olup davah yönetici aleyhine tazminat davaš açılması yönünde alınmış bir genel kurul kararının olup olmadığ dosya kapsamından anlaşılamamaktadır. Böyle bir kararın varlığı dava şartı olup, mahkemece kendiliğinden gözetilmesi gerekir. Bu durum karşısında mahkemece, genel kurulda davalı hakkında dava açılması yönünde alınmış bir karar var ise ibrazının sağlanması, yoksa anılan eksikliğin giderilmesi için davacı tarafa HMK'nın 54. maddesi uyarınca uygun süre verilmesi ve sonucuna göre bir karar verilmesi gerekirken yazıl şekilde doğrudan işin esasına girilerek hüküm kurulması doğru görülmemiş, kararın bozulması gerekmiştir.", Y. 11. HD. E. 2016/1271, K. 2016/8111, https: //www. kararara. com (Erişim Tarihi: 17. 09. 2018). Örnek diğer Yargitay kararları için bkz. Y. 11. HD, T. 12. 07. 2017, E. 2016-8829/4095; Y. 11. HD, T. 26. 01. 2017, E. 2016-5455/534; Y. 11. HD, T. 02. 06. 2016, E. 2015-7487/6166; Y. 11. HD, T. 09. 02. 2016, E. 2015-3371/1194, kararların ilgili kısımları için bkz. Helvacı, Sempozyum I, s. 152-154; Y. 11. HD. T. 17. 12. 2015, E. 2015/560, K. 2015/13614, karar metni için bkz. Altaş, Soner, Şirketler Hukukuna İlişkin Yüksek Yargı Kararları, Güncellenmiş ve Genişletilmiş 2. Bası, Ankara: Seçkin Yayıncılık, 2018, s. 653-655.

23 Arslan, Ramazan/Yılmaz, Ejder/Taşpınar Ayvaz, Sema, Medeni Usul Hukuku, 3. Baskı, Ankara: Yetkin Yayınları, 2017, s. 292; Görgün, Şanal, Medeni Usul Hukuku, 3. Bası, Ankara: Yetkin Yayınları, 2014, s. 160.

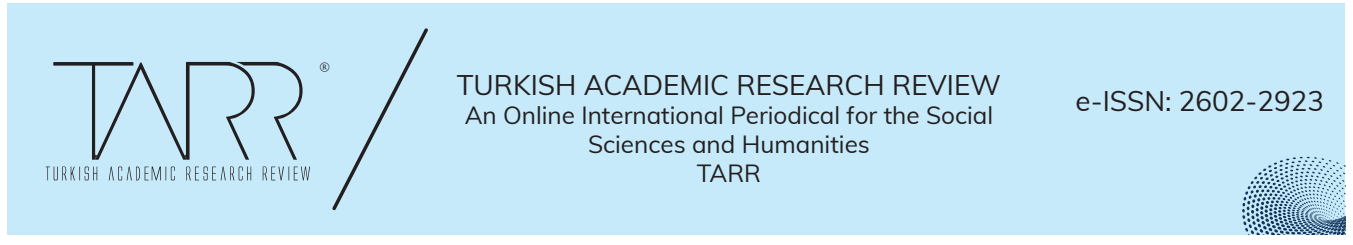




\section{Değerlendirme}

\section{A. 6102 sayılı Türk Ticaret Kanunu Hükümleri Açısından Değerlendirme}

Sorumluluk davası açılmasında genel kurul kararının gerekli olup olmadığına ilişkin doğru bir tespit ve yorum yapılabilmesi için kanaatimizce TTK'nın sorumluluğa ilişkin getirdiği yeniliklerin ve oluşturduğu sistemin ETTK hükümleri ile karşılaştırmalı olarak incelenmesi faydalı olacaktır ${ }^{24}$. Kanaatimizce ancak bu inceleme neticesinde doğru bir değerlendirme yapılması ve soruna ilişkin net bir görüş ortaya konulması mümkün olabilecektir.

\section{6762 sayılı Türk Ticaret Kanunu ile 6102 Sayılı Türk Ticaret Kanunu Düzenle- melerinin Karşılaştırılması}

\section{a. Sorumlu Olanların Kapsamı}

ETTK’nın aksine TTK sorumlu olanların kapsamını dağınık şekilde değil, TTK'nın hukuki sorumluluk başlıklı onbirinci bölümünde düzenli bir şekilde kanunlaştırmıştır. Kurucuların, yönetim kurulu üyelerinin, yöneticilerin ve tasfiye memurlarının sorumluluğu TTK m. 553 hükmünde; denetçinin sorumluluğu ise bir sonraki TTK m. 554 hükmünde düzenlenmiştir ${ }^{25}$. Sorumluluk düzenlemelerinin bir bütün halinde TTK m. 553 ve devamı maddelerinde yer alması sebebiyle, genel kurul kararının gerekliliğine ilişkin bir hükme yer verilecekse, bu düzenlemeler arasında yer verilmesi gerektiği sonucuna ulaşılması mümkündür.

\section{b. Sorumluluğun Niteliği}

ETTK'da yönetim kurulu üyeleri ve denetçilerin sorumluluğunun niteliği sözleşmesel, kusura dayalı ve müteselsil olmak üzere, temelde üç esas etrafında şekillenmekteydi ${ }^{26}$. TTK'da ise kusura dayalı sorumluluk benimsenmekle birlikte, kusurun ispatını davacıya yükler görünümde düzenleme yapılması yoluna gidilmiştir. TTK’nın 6335 sayılı kanunla değiștirilmeden önceki halinde, denetçilerin sorumluluğu açısından kusuru iddia eden ispatlar hükmüne yer verilirken; kurucuların, yönetim kurulu üyelerinin, yöneticilerin ve tasfiye memurlarının kusurlarının bulunmadığı ispatlanmadıkça sorumlu olacakları düzenlenmişti. Yani denetçilerin kusursuz, diğerlerinin ise kusurlu olduğu peşinen kabul edilmekte ve aksini iddia

24 Sonuca ulaşabilmek için TTK'nın düzenlediği sorumluluk rejiminin bir bütün olarak değerlendirilmesi gerektiği yönünde bkz. Helvacı, Sempozyum I, s. 156.

25 Denetçinin sır saklamadan doğan yükümlülüğünü ise TTK m. 404 hükmünde ayrıca düzenlenmiştir. TTK m. 554 gerekçesinde ise bu ikiliğe sır saklamadan doğan ihlallere TTK m. 554 hükmünün uygulanmayacağı belirtilerek açıklık getirilmeye çalışılmıştır. Ancak TTK m. 404 hükmünde sadece sır saklamadan doğan yükümlülük değil görevin dürüst ve tarafsız şekilde yapılması şartı ile görevin yerine getirilmesine yönelik de yükümlülükler düzenlediğinden eleştirilmektedir. İlgili kısmın çıkartılması yoluyla hükümler arasındaki çelişkili durumun çözülebileceği ancak bu halde dahi ayrı sorumluluk rejiminin uygulanmasının haklılığı bulunmayacağına ilişkin öneri ve eleştiriler için bkz. Odman Boztosun, N. Ayşe, "Yeni Türk Ticaret Kanunu'nda Denetçinin Sorumluluğu, Alman Sistemi mi, İsviçre Sistemi mi??, Arslanlı Bilim Arşivi. s. 3 vd.

26 Aynı yönde bkz. Çamoğlu (Poroy/Tekinalp), Ortaklıklar ve Kooperatif Hukuku, N. 590 vd. ; Bahtiyar, Ortakliklar Hukuku, s. 387; Benzer şekilde Çamoğlu, s. 13 vd.

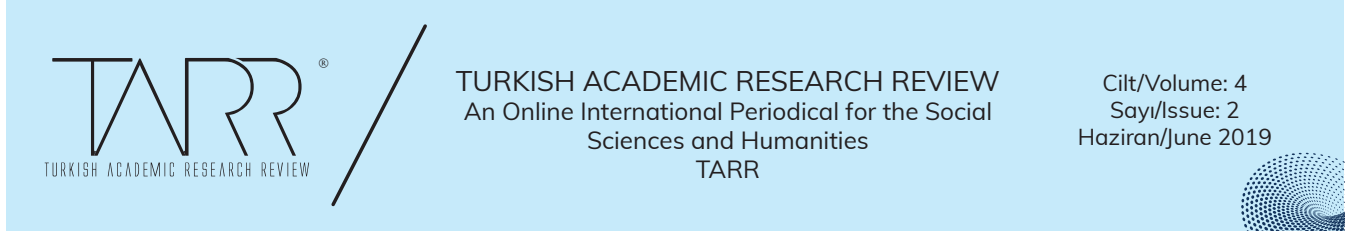


edene, ispat yükü yüklenmekteydi. Değişiklikle birlikte iki sorumluluk açısından bu farklılıklar kaldırılmıştır. Ancak bu halde de sorumluluğun doğması için davalıların kusurlu olmaları dava şartı benzeri bir ifadeyle düzenlendiğinden, davacının ayrıca davalıların kusurları bulunduğunu da ispat etmesi gerekmektedir ${ }^{27}$. Sorumluluğun sözleşmesel olup olmadığına ilişkin de TTK farklı bir yorum yapmayı gerektirmektedir. Sorumlular ile şirket arasında sözleşmesel bir ilişki varsa sorumluluk sözleşmesel, bir sözleşmeye dayanmıyorsa da haksız fiil sorumluluğu kapsamında değerlendirilecektir ${ }^{28}$. Kusurun ispatının davacıya yüklenmesi de davalılar açısından dolaylı bir koruma sağlamaktadır. Sonuç olarak davanın görülmesi ve karara varılması süreci davacılar açısından yeterince güç ve sıkıntılı iken, daha davanın açılma aşamasında, olmayan engelleri varmış gibi yorumlamak ve davacı aleyhine yorum yoluyla bir engel daha çıkarmanın haklılığı ve yerindeliği de ayrı bir tartışma konusudur ${ }^{29}$.

ETTK'da yönetim kurulu ve denetçilerin sorumluluğu mutlak teselsül olarak düzenlenmişti. Bunun sonucunda da bir tazminata hükmedilmesi halinde, tüm sorumlular aynı şekilde ve tazminatın tümünden sorumlu tutulmuşlardı. Ancak TTK'da farklılaştırılmış teselsül ilkesi benimsenmiş ve zararı tazmin etmekle yükümlü kişilerin her birinin somut olaydaki kusurlarına ve durumun gereklerine göre zararın kendilerine yüklenebileceği ölçüsünde, diğerleri ile birlikte müteselsilen sorumlu olacakları hüküm altına alınmıştır (TTK m. 557/1) ${ }^{30}$. Davac1 zarardan kimin ne oranda sorumlu olacağını çoğu zaman tespit edemeyeceğinden, zararın tamamı için sorumlu gördüklerini birlikte dava etmek imkanına sahiptir. Bu davada hakim, davalılardan her birinin sorumluluk miktarını ayrı ayrı tespit edecek ve somut olaya göre davalıların bir kısmı için dava reddedilebilecekken, bir kısmı için de kabul edilebilecek ve bu kişiler farklı oranlarda tazminatla sorumlu tutulabileceklerdir. Farklılaştırılmış teselsül ilkesi, özellikle yönetim kurulunun özden denetimi hayata geçirmesi açısından önemli bir imkan olarak değerlendirilebilir. Nitekim bu sayede sorumluluğu olmadığına inanan yönetim kurulunun çoğunluğunun, sorumluluk davası açılmasına yönelik irade oluşturması oldukça kolaylaştırılmıştır. Pratikte kendi kendini dava etmek olarak algılansa da bu durum, kurul olarak çalışan yönetim kurulunu oluşturan kişiler açısından ayrıca değerlendirilmelidir. Nitekim sorumluluğu olanlara göz yuman kurulun diğer üyeleri, sırf bu sebeple dahi dava açma hakkı olan diğer kişilerin karşısına çıktıklarında sorumlu tutulabilme riski altında olacaklardır. Bu sebeple de farklılaştırılmış teselsül ilkesi yönetim kurulunu oluşturan üyeler açısından

27 Bahtiyar, Ortaklıklar Hukuku, s. 388 vd. ; Objektifleştirilmiş özen ölçüsü kullanılarak yükümlülük ihlalinin ispatı halinde kusurun aksi ispat edilemeyecek şekilde var olduğunu kabul ederek ispat sorununun aşılabileceği yönünde bkz. Akdağ Güney, s. 138.

28 Bahtiyar, Ortakliklar Hukuku, s. 391.

29 Kusurun ispatı yükümlülügüyle sorumlu tutulmanın daha da zorlaştırıldığı yönünde bkz. Bora, Sevda, Şirkete Borçlanma Yasağı, Ankara: Seçkin Yayıncılık, 2017, s. 124, dn. 409.

30 ETTK döneminde birbirini seçmek yetkileri bulunmayan kişilerden oluşan bir kurulda üyelerin müteselsil olarak sorumlu olmalarının adil olmamakla birlikte bu durumda görevi kabul etmemeleri imkânı bulunduğu ve kusur karinesi ile müteselsil sorumluluğun davacılara önemli kolaylıklar sağladığı yönünde bkz. Çamoğlu, s. 22 vd. ; müteselsil sorumluluğun adil ve insan haklarıyla bağdaştırılmasının mümkün olmadığına yönelik görüş için bkz. Tekinalp, N. 12-01 ve 16-139.

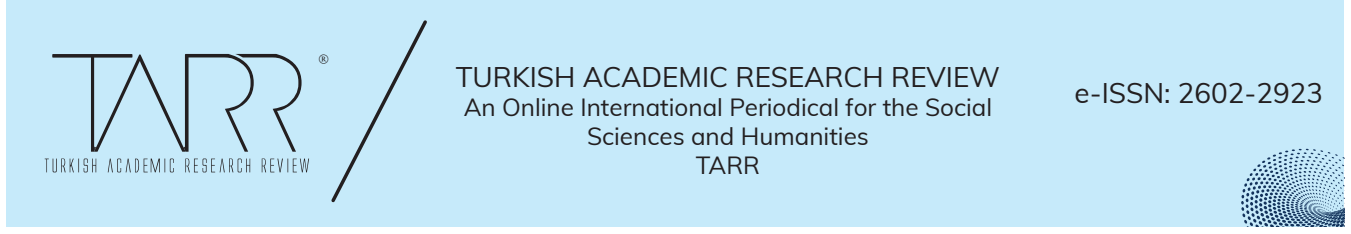


da sorumluluk davasının açılması yönünde irade göstermelerini teşvik edici bir etkiye sahip olacaktır ${ }^{31}$.

\section{c. Davacıların Kapsamı}

Şirketin uğradığı zararın tazminini talep etmek hakkı öncelikle şirkete aittir ${ }^{32}$. ETTK döneminde şirketin sorumluluk davası açabilmesi için genel kurulda bu yönde bir karar alınması ya da esas sermayenin en az onda birini oluşturan pay sahiplerinin dava açılması yönünde oy kullanması gerekmekteydi ${ }^{33}$. TTK'da ise şirket zararlarının talep edilmesi TTK m. 555 hükmünde genel olarak düzenlenmiş olup, hüküm uyarınca şirketin uğradığı zararın tazminini, şirket ve her bir pay sahibi isteyebilir. ETTK'nın aksine şirketin zararı talep etmesi TTK'da açıkça bir genel kurul kararına bağlanmamıştır ${ }^{34}$. Ancak imtiyazlı oyların kullanımına ilişkin sınırlamaları düzenleyen TTK 479/3-c hükmünde sorumluluk davası açılması kararında oyda imtiyaz hakkının kullanılamayacağı düzenlenmiş ve bu düzenleme sorumluluk davası açılması açısından genel kurul kararı alınmasının gerekli olup olmadığı noktasında yukarıdaki bölümlerde de detaylı olarak incelediğimiz gibi doktrinde ciddi tartışmalara yol açmıştır ${ }^{35}$.

ETTK sorumluluk davası açılması talebini, pay sahipleri açısından bir azlık ${ }^{36}$ hak$\mathrm{k1}^{37}$ olarak düzenlenmişti. Azlığ 1 oluşturabilecek pay sahipliği oranı, halka açık

31 Anlaşılması güç ve uygulaması yeterince açık ve net olmadığı için esinlendiği hukuk sistemlerinde de ciddi eleştirilere uğrayan farklılaştırılmış teselsüle ilişkin eleştiriler ve değerlendirmeler için bkz. Akdağ Güney, s. 216 vd.

32 Her ne kadar şirketle birlikte pay sahipleri ve alacaklılara da dava hakkı tanınmış olsa da bu kişiler de zararın şirkete ödenmesini talep edebilecekleri için yine şirket davacı olarak öncelikli kalmaktadır. Bkz. Çamoğlu, s. 109 vd.

33 ETTK m. 341/1 hükmü şu şekildeydi: "Umumi heyet; idare meclisi azaları aleyhine dava açılmasına karar verirse yahut dava açılmamasına karar verilip de esas sermayenin en az onda birini temsil eden pay sahipleri dava açılması reyinde bulunursa, şirket, bu karar veya talep tarihinden itibaren bir ay içinde dava açmaya mecburdur. Bu müddet geçirilmesiyle dava hakkı düşmez. Murakıpların ve alacaklıların vekilinin mesuliyeti hakkındaki hükümler mahfuzdur."

34 Azlık hakkı yerine pay sahibi hakkına çevrilmesinin bile sorumluluk davası açılmasının önündeki engelleri mümkün olduğunca kaldırmak şeklinde anlaşılması gerektiğine yönelik bkz. Helvacı, Sempozyum I, s. 157.

35 Bkz. Bölüm I: Genel Kurul Kararının Gerekli Olup Olmadığına İlişkin Doktrindeki Görüşler.

36 Her ne kadar literatürde azınlık kavramının daha yerinde olduğu yönünde görüşler ileri sürülse de TTK, azlık kavramını kullandığı için ve TTK ile kavram birliği sağlanması gerektiğini düşündüğümüzden, çalışmamızda azlık kavramını kullanmayı uygun görmekteyiz. Çoğunluğun karşıtının azınlık olması gerektiğine yönelik görüşler için bkz. Hasan Pulaşlı, Şirketler Hukuku Şerhi, Cilt II, Ankara: Adalet Yayınevi, 2011, \$39, N. 16 ve 17 ; Azlık ifadesinin Türkçe’de karşılığı olmadığı, doğrusunun azınlık ifadesi olduğu yönünde bkz. Moroğlu, Değerlendirme ve Öneriler, s. 215 ; Bahtiyar, Mehmet, "Türk Ticaret Kanun Tasarısının Dili ve Bazı Hükümlerinin Değerlendirilmesi”, TBB Dergisi. S. 61, 2005, s. 50.

37 Azlık hakları, anonim ortaklığa egemen olan çoğunluk ilkesinin sakıncalarını gidermek, azınlıkta kalan pay sahiplerinin menfaatlerini korumak ve çoğunluğun baskısına engel olmak amacıyla, sermayenin belli bir oranına sahip ortaklara tanınan haklar şeklinde tanımlanabilir. Tanımlar için bkz. Poroy (Tekinalp/ Çamoğlu), Ortaklıklar ve Kooperatif Hukuku, N. 753; Pulaşlı, Genel Esaslar, N. 30-40; Moroğlu, Erdoğan "Anonim Ortaklıkta Azınlık Paysahiplerinin Korunması ve Haklı Nedenle Fesih", Ord. Prof. Dr. Halil Arslanlı'nın Anısına Armağan, İstanbul, 1978, s. 463; Bahtiyar, Ortaklıklar Hukuku, s. 307; Azlık haklarının, azlığın tek taraflı irade açıklamasıyla, kural olarak yöneltildiği organın onayına bağlı olmaksızın kullanılabilen ve hakkın kötüye kullanımı denetimine tabi olan haklardır şeklinde de tanımlanabileceğine yönelik bkz. Helvacı, Mehmet, "Anonim Ortaklıkta Ticaret Kanunundan Kaynaklanan Azınlık Haklarının Hukuki Niteliği ve Tanımı”, Prof. Dr. Oğuz İmregün’e Armağan, İstanbul, 1998, s. 309; Moroğlu, Erdoğan,

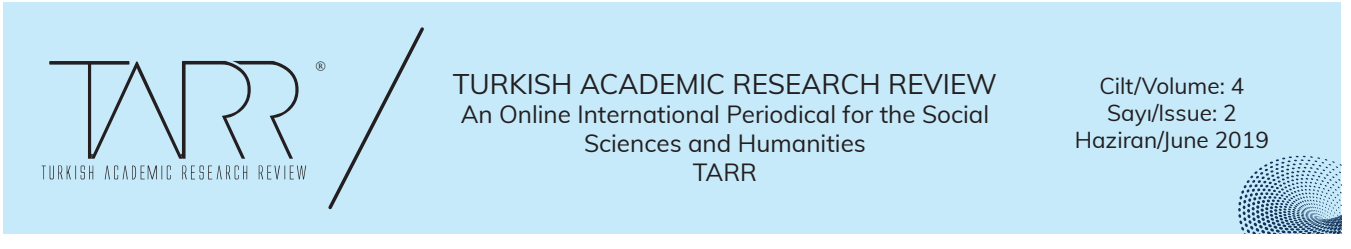


anonim şirketlerde azlık haklarının kullanımını kolaylaştırmak amacıyla ödenmiş sermayenin yirmide biri olarak belirlenmişken, kapalı anonim ortaklıklarda bu oran kural olarak ${ }^{38}$, esas sermayenin onda biridir ${ }^{39}$. Bu oranı birden fazla pay sahibi oluşturabileceği gibi tek bir ortağın da esas sermayenin onda birine sahip olması halinde azlığı tek başına oluşturması mümkündür ${ }^{40}$. ETTK'da azlık hakkı olarak düzenlenen dava açılmasını talep etme hakkı TTK'da pay sahibi hakkı olarak düzenlenmiş ve dava açabileceklerin kapsamı oldukça genişletilmiştir. Pay sahipleri ETTK döneminde olduğu gibi yine tazminatın ancak şirkete ödenmesini isteyebilirler (TTK m. 555/1). Her ne kadar pay sahiplerinin dolaylı zarar gören olabileceği düşünülerek bu hüküm düzenlenmiş olsa da pay sahiplerinin doğrudan zararlarının bulunması halinde, tazminatın kendilerine ödenmesini talep etmeleri de mümkündür ${ }^{41}$. Aktif dava ehliyetinin şirkette olması normaldir, ancak şirketin ihmâli veya sorumluların şirkete hâkim olmaları sebebiyle davanın açılmama ihtimalinin önüne geçilmesi için dava açma hakkının şirketin her bir pay sahibine tanınması yerinde bir değişiklik olmuştur. Esasen yönetim kurulu üyelerinin şirkette pay sahibi olmaları, TTK'da ETTK'nın aksine bir zorunluluk olarak düzenlenmemiştir. Ancak sembolik pay sahipliği sayesinde, yönetim kurulu üyelerinin kurul olarak karar alamamaları halinde pay sahipliği hakkına dayanarak sorumluluk davası açma imkanı olacaktır ${ }^{42}$. Bu imkan, yönetim kurulunun dava açma kararı alamayacağı görüşünün uygulamadaki baskınlığı sebebiyle ayrıca değer kazanmaktadır ${ }^{43}$.

ETTK şirket genel kurulu ve azlık dışında dolayısıyla zarar gören alacaklı ve pay sahiplerine de dava hakkı tanımaktaydı (ETTK m. 309). Ancak bu hallerde de şirket zararlarının şirkete ödenmesi mümkündü. Şirketin iflası durumunda bu haklar iflas masasına geçmekteydi. TTK ise şirketin borçlarını ödediği sürece

Türk Ticaret Kanunu'na Göre Anonim Ortaklıkta Genel Kurul Kararlarının Hükümsüzlüğü. Altıncı Baskı, İstanbul: On İki Levha Yayıncilık, 2012, s. 16 vd.

38 Nitekim TTK m. 411'e göre bu oranın esas sözleşme hükmüyle azaltılması mümkündür.

39 Kırca, İsmail/ Şehirali Çelik, Feyzan Hayal/ Manavgat, Çağlar, Anonim Şirketler Hukuku, C. I, Ankara: Banka ve Ticaret Hukuku Araştırma Enstitüsü (T. İş Bankası A. Ş. Vakfı), 2013, s. 119; Bilgili/Demirkapı, s. 533.

40 Poroy (Tekinalp/Çamoğlu), Ortaklıklar ve Kooperatif Hukuku, N. 753.

41 Konuya ilişkin örnek bir Yargıtay kararının ilgili bölümü şu şekildedir: “...esas sermayenin arttırılması sonrasında nakdi sermayenin 1/4 ünün nakden ödenmek durumunda kalınması, bakiye kısmın ödenmesi için de davah yönetim kurulu üyelerinin 15 günlük gibi kısa bir süre tamımaları sebebiyle davacıların zarar gördüğ̈̈ iddiası, doğrudan zarar niteliğinde bulunup, davacılar tarafından varsa belirlenen zararın tazminini talep edilebilecektir." Y. 11. HD, T. 09. 06. 2016, E. 2015/14405, K. 2016/6410, http: //www. ticaretkanunu. net/ ttk-madde-555/ (Erişim Tarihi: 01. 06. 2018)

42 Konuya ilişkin bir Yargıtay kararının ilgili kısmı şu şekildedir: "kooperatifin uğradığı zararın tazminini kooperatif tüzel kişiliği ve her bir ortağın talep edebilmesi mümkündür. Ortaklar tazminatın ancak kooperatife ödenmesini isteyebilirler. Somut olayda davacılar denetim kurulu üyeleri olmakla beraber ayn zamanda kooperatif ortağı durumundadırlar. Bu durumda davacıların anılan sıfatla davada aktif husumet ehliyetleri bulunduğu kabul edilerek davanın esasına girilmesi gerekirken, aksi düşüncelerle davanın dava şartı noksanlı̆̆ından bahisle usulden reddine karar verilmesi usul ve yasaya aykırı olmuş, bozmayn gerektirmiştir." https: //www. lexpera. com. tr/ictihat/yargitay/23-hukuk-dairesi-e-2015-7888-k-2016-1753-t-21-3-2016 (Erişim Tarihi: 07. 12. 2018).

43 Sembolik pay sahipliği sayesinde şirkete borçlanma şartları açısından da farklı bir uygulamaya dahil olunabilmesi karşısında yönetim kurulu üyelerinin pay sahibi olma zorunluluğunun kaldırılmasının pratikte olumlu bir işlevi olmayacağı yönünde bkz. Bora, s. 110 vd.

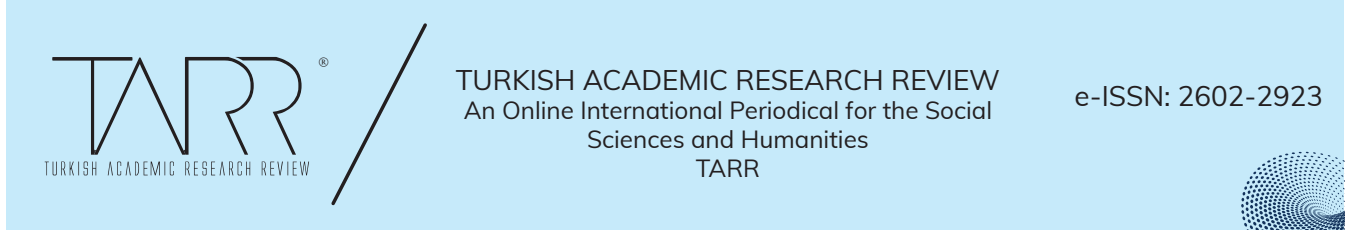


alacaklının zarara uğramadığı varsayımını kabul ederek, pay sahibi ve alacaklıları ayırmış ve sadece şirketin iflası durumunda şirket zararını talep etme hakkını alacaklılara tanımıştır (TTK m. 556/1).

\section{d. Davada Şirketin Temsili}

ETTK döneminde şirket adına dava açma yetkisi denetçilere tanınmıştı (ETTK m. 341/2). Her ne kadar ETTK'da sorumluluk davasında şirketi, şirket denetçisinin temsil edeceği düzenlenmişse de azlığın talebiyle dava açılması halinde, azlık, denetçiler dışında da bir vekil tayin edebilmekteydi ${ }^{44}$. Ayrıca sorumluluk davası açıldığı andaki mevcut yönetim kurulu tamamen değişmiş ise denetçiler dişında yönetim kurulunun da davayı şirket adına açmasında sakınca olmayacağı, aynı zamanda denetçiler de davalı ise o halde kayyım atanması yoluyla çözüme gidilebileceği ileri sürülmekteydi ${ }^{45}$.

TTK şirket organları olarak yalnızca genel kurul ve yönetim kurulunu düzenlemiş ve denetçiler bir organ olmaktan çıkarılmıştır ${ }^{46}$. Şirketin davada temsili ise yönetim kurulunun görev ve yetkileri kapsamındadır. Ancak somut olayın gerektirdiği durumlarda tüm yönetim kurulu üyelerinin sorumluluk davasında davalı olarak yer alması halinde, her ne kadar şirket tüzel kişiliği ve yönetim organını oluşturan gerçek ya da tüzel kişilerin kişilikleri ayrı olsa da şirket menfaatlerinin gerektirdiği durumlarda şirketin kayyım tarafından temsili de mümkün olmalıdır ${ }^{47}$. Ayrıca şirketi dava açılması anındaki mevcut yönetim kurulu temsil edecektir ${ }^{48}$. Özellikle her olağan genel kurul toplantısında gündemde madde bulunması halinde ${ }^{49}$

44 Azınlık vekilinin hukuki durumu ise ETTK döneminde tartışmalı olup şirketle birlikte davayı izleme hakkı tanınan ya da asli müdahil olduğu şeklinde görüşler ileri sürülmekteydi. görüşler için bkz. Çamoğlu, s. 119 vd. , Azlığın bu davada davacı sıfatının olmadığı yine davanın niteliği gereği şirket tarafından açıldığı yönünde görüş için bkz. Helvacı, Sempozyum I, s. 144.

45 Çamoğlu (Poroy/Tekinalp), Ortaklıklar ve Kooperatif Hukuku, N. 600.

46 Nitekim denetçilerin genel kurul kararıyla atanmaları sebebiyle bağımsızlığı ETTK döneminde de oldukça eleştiri konusu edilmekteydi. Bu eleştiriler neticesinde de yönetim kurulunun bir uzantısı vasfında olan bu organa TTK'da yer verilmemiş ve şirketlerin dışardan denetimi esası kabul edilmiştir. Ancak TTK genel gerekçesi N. 129'da denetçilerin organ olmaktan çıkarıldığı belirtilmekle birlikte TTK m. 530 gerekçesinde zorunlu organ teriminin anlamının mahkeme kararlarına bırakıldığı belirtilerek çelişkili bir ifade kullanılmıştır. Bu sebeple denetçinin organ sıfatının olup olmadığı konusu tartışmalı hale gelmiş olup, konuya iliş̧kin ayrıntılı bilgi için bkz. Köksal, Aytaç, "Türk Ticaret Kanunu Tasarısının 309 İla 406 Maddeleri Arasında Düzenlenen Denetçinin Anonim Ortaklı̆̆ın Bir Organı Olup Olmadığı Sorunu”, Prof. Dr. Fırat Öztan'a Armağan, Ankara, 2010, s. 1387-1419; Genel kurulu toplantıya çağırmak ya da genel kurul kararlarına karşı iptal davası açmak gibi organsal yetkileri olmadığı gerekçesiyle denetçilerin organ olmadığı yönünde bkz. Tekinalp, N. 11-05 ve 17-01; Poroy (Tekinalp/Çamoğlu), Ortaklıklar Hukuku I, N. 518; Bahtiyar, Ortaklıklar Hukuku, s. 145; Pulaşl1, Genel Esaslar, N. 19-3; Bilgili/Demirkapı, s. 257; denetçilerin organ olarak kabul edilmemeleri gerektiği ancak TTK'nın denetçilerin sorumluluğunu ve ibrasını özel olarak düzenlemelerine dahil etmesi sebebiyle, gerekçedeki çelişkilere ek olarak ilgili hükümler sebebiyle de denetçinin organ niteliğinin tartışmalı hale geldiği yönünde benzer açıklamalar için bkz. Kırca (Şehirali Çelik/Manavgat), s. 394.

47 ETTK dönemi için de denetçilerin de davalı olması halinde durum bu şekilde çözüme kavuşturulmuştur. Bkz. Çamoğlu, s. 122.

48 Çamoğlu, s. 122.

49 Genel kurul gündemini yönetim kurulu belirlediğinden genellikle yönetim kurulu dışında diğer kişilerin ve tasfiye memurları gibi organların genel kurulu toplantıya çağırması halinde gündemde yönetim kurulu üyelerinin değiştirilmesi maddesinin yer alabileceğine ilişkin bkz. Şener, a. 362. Ancak süresi dolan yönetim kurulunun da yönetim kurulu üyelerinin seçimi gündemiyle genel kurulu toplantıya çağırma yetki

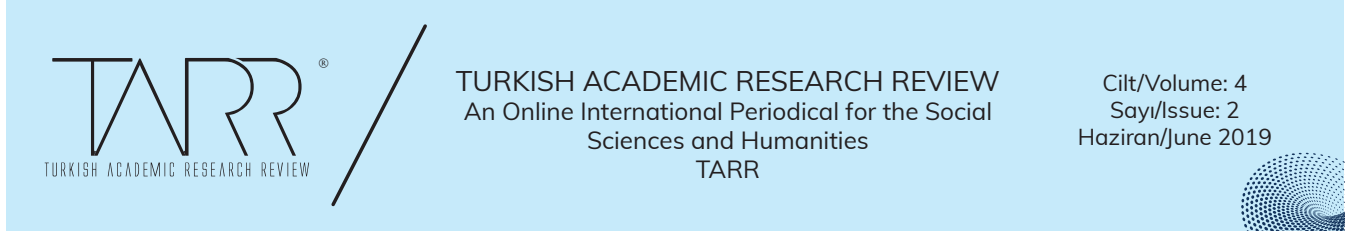


ya da gündemde madde bulunmasa bile, yılsonu finansal tablolarının müzakeresi maddesi de yönetim kurulu üyelerinin atanmaları ve görevden alınmalarıyla ilgili kabul edildiğinden, bu gündem maddesinin bulunması neticesinde ya da haklı bir sebebin bulunması halinde olağan veya olağanüstü genel kurulda her zaman yönetim kurulu üyeleri görevden alınabilir ${ }^{50}$. Bu görevden alma kararı tüm yönetim kurulunu değiştirme şeklinde olabileceği gibi yönetim kurulu üyelerinin bir kısmının görevden alınması şeklinde de olabilir ${ }^{51}$. Bu sebeple dinamik bir yapısı olan yönetim kurulunun kolaylıkla yenilenebilmesi karşısında, özellikle yönetim kurulu tarafından sorumluluk davası açılması hallerinde genellikle davalılar eski yönetim kurulu üyeleri olmaktadır. ETTK m. 337 hükmünde açıkça yeni seçilen yönetim kuruluna, eski yönetim kurulunun açık olan yolsuzluklarını denetçilere bildirme yükümlülüğü yüklenmiş ve aksi halde onların sorumluluğuna iştirak etmiş kabul edilecekleri belirtilmişti. Benzer bir hükme TTK'da açıkça yer verilmemekle birlikte, eski yönetim kurulunun açık yolsuzluklarının tespiti özellikle onaylanan bilançonun gerçeği yansıtmaması sebebiyle örtülü ibrayı ortadan kaldırıcı nitelikte olacağından ve şirketin menfaatinin korunması da şirkete bu şekilde zarar verenlerden hesap sorulmasını gerektireceğinden, ETTK döneminde olduğu gibi TTK döneminde de yeni yönetim kurulunun, eski yönetim kurulunun sorumluluk gerektiren iş ve işlemlerini inceleme görevi devam etmektedir.

\section{e. Yargilama Masrafları}

ETTK döneminde azlığın ve dolayısıyla pay sahiplerinin dava açmaları üzerine, şirket hisse senetlerini dava sonuna kadar teminat olarak bankaya yatırmaları gerekmekteydi. Ayrıca davanın reddi halinde davacılar şirkete karşı tazminat ödemekle de yükümlü tutulmuşlardı (ETTK m. 341/2). Bu yükümlülük ise uygulamada sorumluluk davası açılmasında azlığın çekimser davranmasına yol açmaktaydı. Ayrıca dava masrafları sebebiyle de yönetim kurulu üyelerine sorumluluk davası açılması genel kurulun takdirine bırakılmıştı. Nitekim bu durumda masraflara katlanması gereken şirket tüzel kişiliği olmaktaydı.

ETTK döneminde pay sahiplerinin dava açılmasını talep etmekte çekimser davranmalarına sebep olan yargılama giderleri açısından, TTK bir çözüm üretmiştir ve pay sahiplerinin şirket zararlarının tazmini için talepte bulunmalarının teşvi-

ve görevine sahip olduğu gözden kaçırılmamalıdır.

50 Sonuç olarak her olağan genel kurul toplantısında yönetim kurulu üyelerinin görevden alınmaları mümkün ve görevde kalmaları sakıncalı kişilerin görevi sürdürmelerinin önüne geçilmesinin gerekli olması karşısında TTK m. 364 hükmünde ilgili maddenin bulunması ya da bulunmasa bile haklı bir nedenin bulunması şeklinde değil sadece her zaman şeklinde görevden almanın düzenlenmesi gerektiği yönünde öneri için bkz. Moroğlu, Değerlendirme ve Öneriler, s. 162.

51 Genel kurul bu kararını kanunda aksine daha ağır nisap öngörülmüş bulunmadığından sermayenin en az dörtte birini karşılayan payların sahiplerinin veya temsilcilerinin varlığıyla toplanarak, bu toplantı nisabı sağlanamadığı takdirde, ikinci toplantıda nisap aranmaksızın ve her halükârda toplantıda hazır bulunan oyların çoğunluğu ile alır. TTK m. 340 hükmü karşısında kanunda açıkça esas sözleşmede aksine bir düzenleme yapılmasına imkân tanınmadığından bu toplantı ve karar yetersayısına ilişkin esas sözleşme hükmü ile değişiklik yapılması kanaatimizce mümkün değildir. TTK kurullar arasındaki ilişkiyi güvene dayandırdığından seçim ve azillerde ve aynı şekilde sorumlulukta olabildiğince esnek ve hızlı hareket edilmesini sağlamaya önem vermiştir. Yönetim kurulunun azlinde toplantı ve karar nisabının ağırlaştırılabileceğine ilişkin aksi görüş için bkz. Akdağ Güney, s. 39.

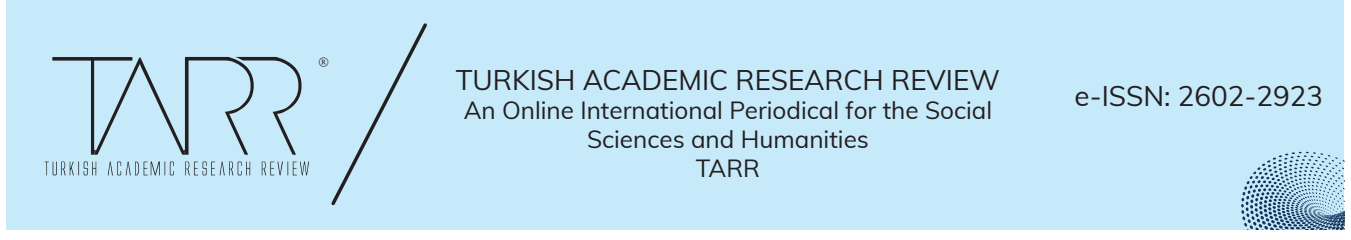


ki amacıyla davanın kaybedilmesi halinde dava giderleriyle avukatlık ücretinin davacı pay sahibiyle şirket arasında, hakkaniyete göre paylaştırılabileceğini düzenlemiştir ${ }^{52}$. Ancak bunun için hukuki ve maddi sebepler dava açılmasını haklı göstermelidir (TTK m. 555/2).

\section{Görüşümüzz}

Kanaatimizce, ETTK ve TTK'nın sorumluluğa ilişkin düzenlemelerinin karşılaşt1rılması neticesinde, doktrindeki hem yönetim kurulunun ve hem de genel kurulun sorumluluk davası açılmasına karar verebileceğini ileri süren üçüncü görüş, TTK sistematiğine ve kanuni yorum ilkelerine daha uygun görünmektedir. TTK genel olarak değerlendirildiğinde, genel kurulda sorumluluk davası açılmasına ilişkin bir karar alınmasına imkân verildiği görülmektedir. Ancak bu davanın her bir pay sahibine tanınmasına imkân sağlanması karşısında, evleviyet ilkesi gereği yönetim kurulunun da dava açabilmesi gerekmektedir. Nitekim sorumluluk davasının şirket tarafından açılacağı düzenlemesi karşısında, davada şirketi yönetim kurulunun temsil edeceği açıktır. Aynı şekilde dava açma kararının da yönetim kurulu tarafından alınması, TTK'da açıkça yasaklanmamakta ve engellenmemektedir ${ }^{53}$.

Sorumluluk davası açılmasına şirket karar vereceğinden, öncelikle bu yetki yönetim kurulundadır. Ancak yönetim kurulunda karar alınamaması veya sorumluluk davası açılmasının istenmemesi hallerinde, TTK m. 479/3-c hükmü gereğince genel kurul da sorumluluk davası açılması kararı alabilir. Genel kurulda sorumluluk davası açılması yönünde bir karar alınması üzerine, yönetim kurulu genel kurul kararlarını yürütmekle görevli olduğundan, davayı kendi aleyhine de olsa açmak zorunda kalacaktır. Neticede davayı mevcut yönetim kurulunun açması gerekmektedir. Sorumluluk davası açılması kararı alınan bir genel kurulda sorumlu olduğu düşünülen yönetim kurulu üyelerinin görevde tutulmaya devam edilmesi de pek mümkün olmadığından, genellikle sorumluluk davası açılması kararı ile birlikte ilgili üyelerin görevden alınmaları kararı da alınır. Bu sebeple davayı genellikle yeni yönetim kurulu açacağından, yargılamada menfaat çatışmas1 söz konusu olmayacaktır. Ancak aksi durum da söz konusu olabilir. Sorumlu olduğu düşünülen yönetim kurulunun görevde bırakılması halinde de durum değişmeyecektir ${ }^{54}$. Yönetim kurulu ya bu davayı açacaktır ya da sorumlu olmadığını düşünüyor ve bu kararı uygulanmaması gerekli bir karar olarak değerlendiriyorsa, genel kurulun sorumluluk davası açılması kararına karşı iptal davası açmalıdır. Aksi halde genel kurul kararlarını yerine getirmeyen yönetim kurulu için bu durum, kanaatimizce gündemde madde olmasa bile yönetim kurulu üyelerinin azli ve yenilerinin seçilmesi için bir haklı neden teşkil edecektir. Sonuç olarak sorum-

52 Bkz. TTK m. 555 gerekçesi; Hükmün olumlu bir değişiklik getirdiği yönünde bkz. Helvacı, Mehmet, "Anonim Ortaklık Yönetim Kurulu Üyelerinin Hukuki Sorumluluk Sistemindeki Başlica Yenilikler “, Türk Ticaret Kanununun 5. Yıl Sempozyumu. 8- 10 Kasım 2017, Ankara: Türkiye Adalet Akademisi, 2018, s. 351; Tekinalp, N. 16-109.

53 Bu yaklaşımın zaman ve para maliyeti açısından da daha işlevsel ve kolay olduğu yönünde bkz. Helvacı, Sempozyum I, s. 168.

$54 \mathrm{Bu}$ durumun hayatın olağan akışına aykırı olduğu ve pek olası olamayacağı yönünde bkz. Helvacı, Sempozyum I, s. 164.

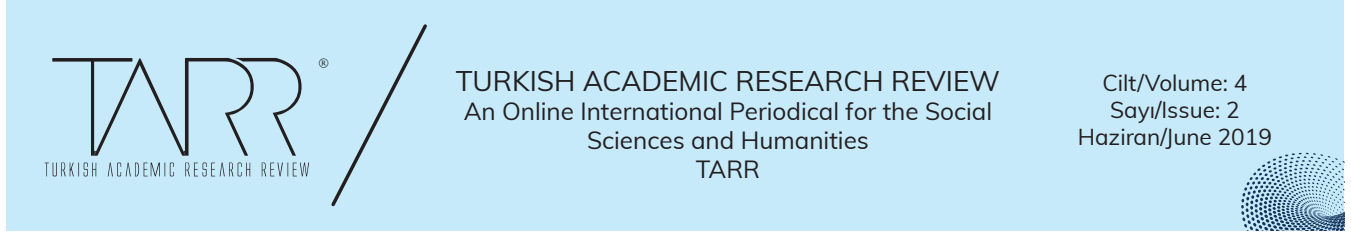


lu olduğu düşünülen yönetim kurulu genel kurul tarafından azledilecek ve yenileri seçilecektir. Ancak bu durumda sorumluluk davası açılması kararını uygulamayan yönetim kurulu üyelerinin bu durumdan kaynaklanan şirket zararlarını da ayrıca tazmin etmeleri gerekecektir 55 .

Sorumluluk davası açılması kararının hem yönetim kurulu ve hem de genel kurul tarafından alınabileceğinin tespitinden sonra tartışılması gereken bir diğer mesele de sorumluluk davası açılması kararının esas sözleşme ile genel kurulun onayı şartına bağlanarak iki organın da aynı yönde hareket etmeye zorlanıp zorlanamayacağıdır ${ }^{56}$. Nitekim bu ihtimal TTK'nın cevaz verdiği bir düzenleme sahasını oluşturmaktadır ki TTK m. 374 gerekçesinde de bu sorunun cevabının öğreti ve mahkeme kararlarına bırakıldığı belirtilmiştir. Kanaatimizce bu sorunun cevabını vermek için göz önüne alınması gereken ilk şey, TTK'nın sorumluluk sistemidir. Özellikle anonim şirketin temel yapısının korunması ve şirkete zarar verilmesinin önüne geçilmesi açısından bu sorumluk sistemini engellemeye yönelik değişiklikler yapılmasının TTK'nın temel felsefesine ne derece uygun olacağının doğru bir şekilde değerlendirilmesi gerekmektedir. Kanaatimizce TTK sorumluluk davası açılmasını teşvik edici düzenlemeler ve sistemler öngördüğünden, bu sorunun olumsuz olarak yanıtlanması gerekmektedir. Yönetim kurulunun da karar alabileceği bir alanın genel kurul onayına bağlanması, TTK'nın öngördüğü sistemde anonim şirketlerin temel yapısına aykırılık oluşturduğundan, böyle bir düzenlemenin esas sözleşmeye eklenememesi gerekir ${ }^{57}$.

Değerlendirilmesi gereken bir diğer önemli mesele de ibra kararının sorumluluk davası açılması üzerindeki etkisidir. TTK m. 558 hükmüne göre genel kurulun, sorumluluktan ibraya ilişkin kararı, ibranın kapsadığı açıklanan maddi olaylara ilişkin olarak, şirketin sorumluluk davası açma hakkını ortadan kaldırmaktadır. İbra kararı, sorumluluk davası açılması kararının aksine, TTK m. 409/1 hükmünde olağan genel kurul toplantısının zorunlu gündemi içeriğinde yer almak$\operatorname{tad}^{5}{ }^{58}$. Ayrıca TTK m. 524 hükmü uyarınca bilançonun onaylanmasına ilişkin genel kurul kararı, kararda aksine bir ifade bulunmadığı takdirde, yönetim kurulu üyelerinin, yöneticilerin ve denetçilerin ibrası sonucunu doğurmaktadır ${ }^{59}$. Ancak bilançoda bazı hususlar hiç veya gereği gibi belirtilmemişse veya bilanço şirketin gerçek durumunun görülmesine engel olacak bazı hususları içeriyorsa ve bu hususta bilinçli hareket edilmişse onama, ibra etkisini doğurmayacaktır ${ }^{60}$. Genel

55 Aynı yönde bkz. Çamoğlu (Poroy/Tekinalp), Ortaklıklar ve Kooperatif Hukuku, N. 596.

56 Sorumluluk davası açılması kararında genel kurul ve yönetim kurulunun müşterek yetkiye sahip olduğu yönünde bkz. Helvac1, Sempozyum I, s. 164.

57 Varılan sonuç açısından benzer bir tespit için bkz. Kırca (Şehirali Çelik/Manavgat), s. 536; Aksi yönde görüş için bkz. Yördem, Yılmaz, Anonim Şirket Yönetim Kurulu Üyelerinin Hukuki Sorumluluğunda Farklılaştırılmış Teselsül İlkesi, Ankara: Seçkin Yayıncılık, 2017, s. 206.

58 Aynı yönde değerlendirme için bkz. Şener, s. 424.

59 Örtülü ibranın bir kanun maddesiyle düzenlenmiş olmasına karşıllk asıl geri alınamaz etkiye sahip olan açık ibranın bir kanun hükmüyle düzenlenmemiş olmasının önemli bir eksiklik olduğu yönündeki eleştiriler için bkz. Moroğlu, Değerlendirme ve Öneriler, s. 16; Açık ibranın TTK m. 558 hükmünde örtülü ibranın ise TTK m. 424 hükmünde düzenlendiğine yönelik bkz. Tekinalp, N. 16-18.

60 Ayrıca açık ibra kararı ya da bilançonun onaylanması kararı ile örtülü şekilde alınan ibra kararı bir genel kurul kararı niteliğinde olduğu için iptal edilmeleri mümkündür. İbra kararı iptal davası dışında başka bir

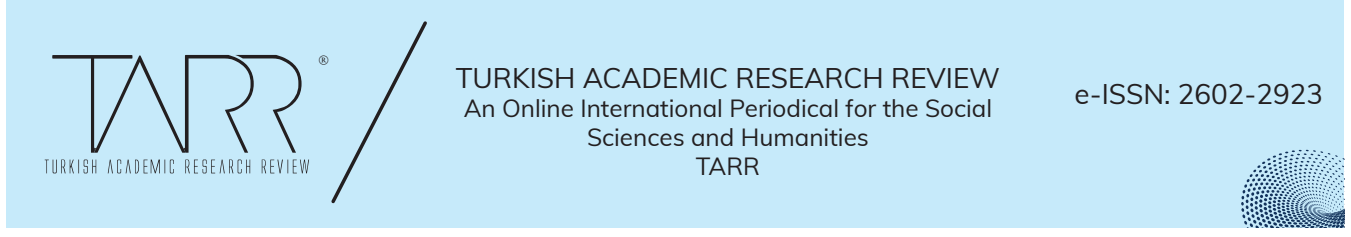


kurulun bu şekilde açık ya da örtülü ibra kararı alarak şirketin sorumluluk davası açmasına engel olma imkânı karşısında dolaylı olarak yönetim kurulunun şirket adına dava açabilmesi için genel kurulun konuya ilişkin bir ibra kararının bulunmaması gerekmektedir. Bu açıdan konuya yaklaşıldığında, sorumluluk davası açılması kararı ile ibra kararı bir madalyonun farklı iki yüzü gibi görünmektedir ${ }^{61}$. Sorumluluk davası açılmasına yönelik genel kurul kararı alınması şartı aranmasa bile, genel kurulun ibra kararını almamış olması şartının aranması gerektiği ortadadır ${ }^{62}$. Ancak bu halde bile ibra kararına olumlu oy vermeyen ve bu durumu bilmeyerek payı iktisap eden pay sahiplerinin sorumluluk davası açma hakları devam etmektedir. İbra kararı, yalnızca şirketin ve bu kararın alınmasında etkili olan pay sahipleri ile bilerek şirket paylarını edinen yeni pay sahiplerinin dava açma hakkını engellemektedir. En nihayetinde bir genel kurul kararı niteliğinde olan bu ibra kararının da yönetim kurulu tarafından iptal davasına konu edilmesi de ihtimal dahilindedir. Nitekim şirketin çıkarlarını göz önüne alarak hareket etmesi gereken yönetim kurulunun, iptal edilmesi gereken genel kurul kararının iptalini istemede ihmale düşmesi halinde, TTK 553 ve devamı maddelerine göre ayrıca sorumlu tutulması mümkündür ${ }^{63}$. Sonuç olarak kanaatimizce genel kurulda sorumluluk davası açılmasına yönelik bir karar alınmaması değil, tam aksine ibra kararı alınması halinde yönetim kurulunun dava açma imkânı ortadan kalkmaktadır. Aynı şekilde yönetim kurulunun da alınan genel kurul kararlarını, şartları sağlanıyorsa iptalini dava etmek hakkı bulunmaktadır. TTK sistematiğinde zaten şirketin sorumluluk davası açmasında hem genel kurulun ve hem de yönetim kurulunun etkin olacağı dava açılmasını engelleyici ya da engelleri kaldırıcı enstrümanları bulunmaktayken, uygulamada tersi yönde ibra kararı olmamasına rağmen bir de açıkça sorumluluk davası açılmasına yönelik bir karar aranması, katı ve bir bakıma şirket zararlarının tazminini engelleyici bir uygulama niteliğindedir.

\section{6100 sayılı Hukuk Muhakemeleri Kanunu Hükümleri Açısından Değerlendirme}

Şirketin sorumluluk davası açabilmesi için bu yönde bir genel kurulu kararı alınmasının gerekli olup olmadığının tespitinde, usul hukuku açısından değerlendirme yapılarak sonuca ulaşılması gerekmektedir. Dava şartları 6100 sayılı Hukuk Muhakemeleri Kanunu (HMK) m. 114/1 hükmünde sınırlı sayıda olmayacak şekilde sayılmış ${ }^{64}$ ve HMK m. 114/2 hükmü ile de diğer kanunlarda yer

genel kurul kararı ile ortadan kaldırılamamaktadır. TTK m. 558/1 hükmünde düzenlenen iptal davasının saklı tutulması hükmünün gereksiz olduğunu ileri süren görüșiçin bkz. Moroğlu, Hükümsüzlük, s. 314, dn. 587 ve Moroğlu, Değerlendirme ve Öneriler, s. 331.

61 Benzer tespit için bkz. Bahtiyar, Armağan, s. 409.

62 İbra edilmeme kararının davanın ön şartı niteliğinde olduğu ve en nihayetinde sorumluluk davasının yine bir genel kurul kararına dolaylı da olsa dayandığı yönünde haklı tespit için bkz. Tekinalp, N. 16-92; İbra kararı nasıl ki genel kurulun devredilemez görev ve yetkilerinden biridir, sorumluluk davası açılması kararının da aynı şekilde değerlendirilmesi gerekir șeklindeki görüș için bkz. Bahtiyar, Armağan, s. 410.

63 Moroğlu, Hükümsüzlük, s. 255 vd; Çamoğlu, Ersin, Anonim Ortaklı Yönetim Kurulu Üyelerinin Hukuki Sorumluluğu, Güncelleştirilmiş ve Genişletilmiş Üçüncü Bası, İstanbul: Vedat Kitapçılık, s. 58 vd. ; Helvacı, Sempozyum I, s. 160.

64 HMK m. 114/1 hükmüne göre dava şartları şunlardır: "a) Türk mahkemelerinin yargı hakkının bulunması.

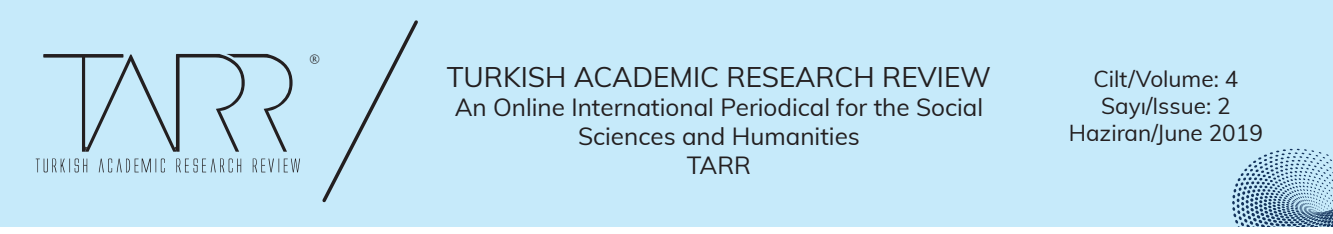


alan dava şartlarına ilişkin hükümler saklı tutulmuştur. Kanun bir durumun varlığ1 veya yokluğunu davanın esastan incelenip karara bağlanmasına engel olarak düzenlemiş ve hâkimi de bu durumu resen incelemekle yükümlü tutmuş ise bu durum dava şartı niteliğindedir ${ }^{65}$. Dava şartlarının bu sebeple, ancak kanunla ve hiçbir tereddüte yer bırakmaksızın açıkça düzenlenmiş olması gerekmektedir ${ }^{66}$. Ancak TTK'da genel kurul kararı alınmasının dava şartı olduğuna ilişkin açık bir hüküm bulunmamaktadır. Yargıtay ise yorum yoluyla ve ETTK uygulamasını göz önüne alarak bu uygulamayı geliştirmiştir.

Genel kurul kararı alınmasının gerekli olarak kabul edilmesi halinde, TTK'da açıklık bulunmadığından, dava şartı olarak değerlendirilmese bile uygulamada benzer sonuçlara yol açabilecek şekilde bu durumun bekletici sorun ${ }^{67}$ olarak da değerlendirilmesi mümkün olabilir. Nitekim bekletici sorun olarak kabul edilmesi halinde, mahkeme davayı açma yetkisi olduğunu kabul ederek yönetim kuruluna süre verecek ve yönetim kurulu da bu süre zarfında sorumluluk davası açılmasına karar verilmesi gündemiyle genel kurulu toplantıya çağıracaktır. Bu durumda, prosedür benzer şekilde işliyor gibi görünse de mahkemenin bekletici sorun yapma kararı zorunlu değil ihtiyari olduğundan, mahkeme, genel kurul kararını beklemeksizin esasa girerek karar verme imkanına da sahip olacaktır ${ }^{68}$. Bu durumda sorumluluk davasının niteliğine göre bazen yönetim kurulunun bazense genel kurulun karar almaya yetkili olabileceği görüşünün usul hukuku açısından uygulamadaki değerlendirme tercihi, genel kurul kararı alınmasını dava şartı yerine bekletici sorun olarak kabul etmek şeklinde gelişim gösterebilir. Ancak bu değerlendirme de genel kurul kararının alınması için harekete geçilmemesi ya da harekete geçilmekle birlikte karar alınamaması halinde, bu durumun hükmü nasıl etkileyeceği belirsiz ve öngörülemez olacağından, eleştiriye açıktır. Her iki ihtimalde de şirketin dava açma hakkı önemli derecede engellenmekte ve yorum

b) Yargı yolunun caiz olması. c) Mahkemenin görevli olması. ç) Yetkinin kesin olduğu hâllerde, mahkemenin yetkili bulunmast. d) Tarafların, taraf ve dava ehliyetine sahip olmaları; kanuni temsilin söz konusu olduğu hâllerde, temsilcinin gerekli niteliğe sahip bulunması. e) Dava takip yetkisine sahip olunması. $f$ ) Vekil aracıllğıla takip edilen davalarda, vekilin davaya vekâlet ehliyetine sahip olması ve usulüne uygun düzenlenmiş bir vekâletnamesinin bulunması. $10894 \mathrm{~g}$ ) Davacının yatırması gereken gider avansının yatırılmış olması. ğ) Teminat gösterilmesine ilişkin kararın gereğinin yerine getirilmesi. h) Davacının, dava açmakta hukuki yararının bulunması. ı) Aynı davanın, daha önceden açılmış ve hâlen görülmekte olmaması. i) Aynı davanın, daha önceden kesin hükme bağlanmamış olması."

65 Arslan/Yılmaz/Taşpınar Ayvaz, s. 281; Pekcanıtez, Hakan/ Atalay, Oğuz/ Özekes, Muhammet, Medeni Usul Hukuku, 7035, 7101 ve 7145 Sayılı Kanunlarla Yapılan Değişiklikler Nazara Alınarak Gözden Geçirilmiş 6. Bası, İstanbul: Vedat Kitapçıllk, 2018, s. 199 vd.

66 Helvaci, Sempozyum I, s. 155.

67 HMK m. 165 hükmünde bekletici sorun başlığıyla şu düzenleme yer almaktadır: "Bir davada hüküm verilebilmesi, başka bir davaya, idari makamin tespitine yahut dava konusuyla ilgili bir hukuki ilişkinin mevcut olup olmadığına kısmen veya tamamen bağh ise mahkemece o davanın sonuçlanmasına veya idari makamın kararına kadar yargilama bekletilebilir.

Bir davanın incelenmesi ve sonuçlandırılması başka bir davanın veya idari makamın çözümüne bağh ise mahkeme, ilgili tarafa görevli mahkemeye veya idari makama başvurması için uygun bir süre verir. Bu süre içinde görevli mahkemeye veya idari makama başvurulmadığı takdirde, ilgili taraf bu husustaki iddiasından vazgeçmiş sayılarak esas dava hakkında karar verilir." Bekletici sorun hakkında ayrıntılı bilgi için bkz. Aşı, İbrahim, Medeni Usul Hukukunda Bekletici Sorun, Ankara: Seçkin Yayıncılık, 2012.

68 Pekcanitez/Atalay/Özekes, s. 296.

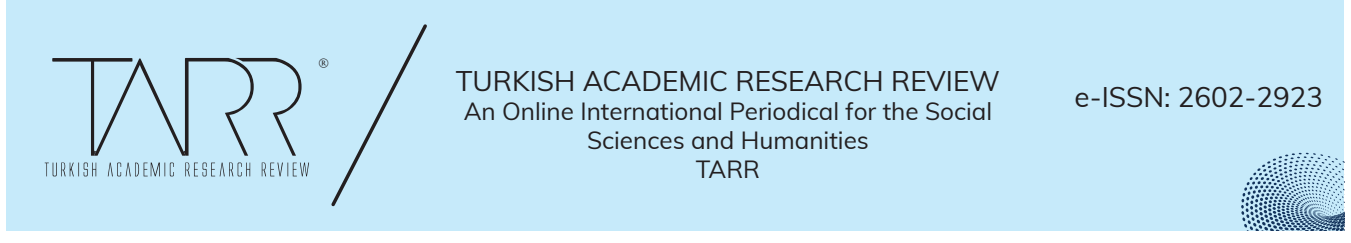


yoluyla getirilen dava şartı ya da bekletici sorun değerlendirmesi yargılamanın akıbeti açısından belirsizliğe yol açmaktadır ${ }^{69}$.

Dava şartı ya da bekletici sorunun şartları oluşmadan, yorum ya da kıyas yoluyla şirketin sorumluluk davası açması durumunda bu yönde bir genel kurul kararı alınmasının dava şartı veya bekletici mesele olarak uygulanması neticesinde, yargılama kesintiye uğratılmakta ve şirketin hak arama hürriyeti geçici de olsa ihlal edilerek engellenmektedir. Hakkın yerine getirilmesinden kaçınılmış olması niteliğinde dahi değerlendirilebilecek bu durum, hakimlerin hukuki sorumluluğunu doğuran sebeplerden biri olarak HMK m. 46/1-e hükmünde düzenlenmiştir ${ }^{70}$. Nitekim bu sorumluluk halinde hâkimin davayı sürüncemede bırakması söz konusudur ${ }^{71}$. Hakkın yerine getirilmesinden kaçınma aynı zamanda şartların sağlanması halinde görevi kötüye kullanma suçunun oluşmasına da sebebiyet verebilecek niteliktedir ${ }^{72}$.

Gerekli olmadığı halde yargılamanın başlamasının yorum yoluyla şartlara tabi tutulması, en nihayetinde usul hukukunun temel ilkelerinden biri olan makul sürede yargılanma ilkesine ve usul ekonomisi ilkesine de aykırılık oluşturmaktadır ${ }^{73}$. Anayasa m. 141 hükmünün son fikrasında davaların en az giderle ve mümkün olan azami süratle sonuçlandırılmasının yargının görevi olduğu vurgulanmıştır. HMK m. 30 hükmünde de hâkim, yargılamanın makul süre içinde ve düzenli bir biçimde yürütülmesini ve gereksiz gider yapılmamasını sağlamakla yükümlü tutulmuştur. Ayrıca bu ilkelere aykırı şekilde hareket edilmesinin AİHS m. 6 hükmünde düzenlenen hak arama özgürlüğünün ihlali sonucunu doğurabileceği de gözden kaçırılmaması gereken önemli bir meseledir ${ }^{74}$.

69 Ayrıca bekletici sorun kararı mahkemenin ara kararı niteliğinde olduğundan HMK kapsamında karara karşı bir kanun yolu öngörülmemiştir. Ancak etkileri göz önüne alındığında nihai bir karar olmasa dahi yargılama ertelendiği için bu süreçte temyize götürülmesinin mümkün olması gerektiği yönünde görüşler ve HMK'da açıkça başvurulabilecek bir kanun yolu öngörülmesi gerektiği yönünde öneriler ileri sürülmektedir. Öneriler için bkz. Așık, s. 240 vd.

70 Hâkimin hukuki sorumluluğu kapsamında açılacak tazminat davasında davalı devlettir ve tazminata hükmedilmesi halinde sorumluluğu tespit edilen hâkime devletin rücu imkânı bulunmaktadır (HMK m. $46 / 3)$.

$71 \mathrm{Bu}$ durumun hukuki sorumluluk yanında cezai sorumluluğa da sebebiyet verebileceği yönünde bkz. Arslan/Yılmaz/Taşpınar Ayvaz, s. 129; Görgün, s. 44 vd.

72 Türk Ceza Kanunu m. 257 hükmü şu şekildedir: "Kanunda ayrıca suç olarak tanımlanan haller dışında, görevinin gereklerine aykır hareket etmek suretiyle, kişilerin mağduriyetine veya kamunun zararına neden olan ya da kişilere haksız bir menfaat sağlayan kamu görevlisi, altı aydan iki yıla kadar hapis cezası ile cezalandırılır.

Kanunda ayrıca suç olarak tanımlanan haller dışında, görevinin gereklerini yapmakta ihmal veya gecikme göstererek, kişilerin mağduriyetine veya kamunun zararına neden olan ya da kişilere haksız bir menfaat sağlayan kamu görevlisi, üç aydan bir yıla kadar hapis cezası ile cezalandırllır."

73 Usul ekonomisi doktrinde kısaca çabukluk, basitlik ve ucuzluk şeklinde ifade edilmektedir. Bilgi için bkz. Arslan/Yılmaz/Taşpınar Ayvaz, s. 156.

74 Aynı yönde Aşık, s. 168; Arslan/Yılmaz/Taşpınar Ayvaz, s. 129; benzer şekilde bkz. Pekcanıtez/Atalay/ Özekes, s. 189.

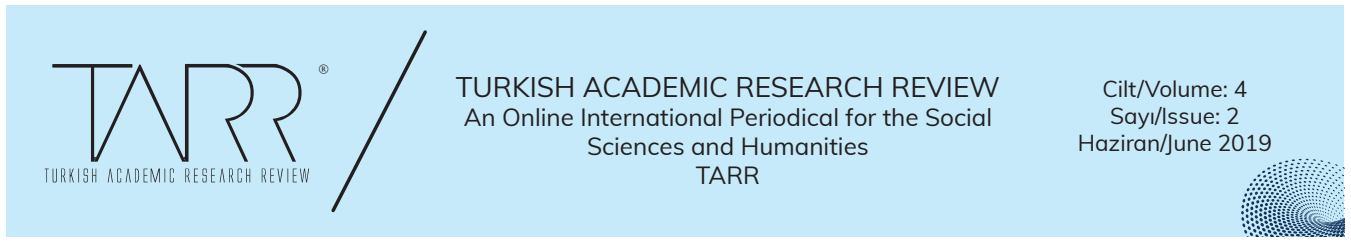




\section{Sonuç ve Çözüm Önerilerimiz}

Şirket zararlarının tazminini şirket adına talep edebilecek olan organ, şirketin yönetimi ve temsili ile görevli olan yönetim kuruludur. Her halükarda açılacak herhangi bir davada şirketi temsille yetkili olan organın yönetim kurulu olduğu açıtır. Ancak TTK m. 479/3-c hükmünde dolaylı da olsa genel kurulun sorumluluk davası açılması kararı almasının düzenlenmiş olmasının elbetteki hukuki bir sonucu olmak zorundadır. Ancak genel kurula tanınan bu yetki hükmünün münhasır değil müşterek bir yetki maddesi olarak değerlendirilmesi gerekmektedir. Sonuç olarak bu yetki maddesi ile mevcut yönetim kurulunda sorumluluk davası açılması kararı alınamaması halinde, genel kurul kararı ile de sorumluluk davası açılması mümkün hale getirilmiştir. Ayrıca sorumluluk davası açılması kararını hangi organ alırsa alsın, uygulayacak organ yine yönetim kuruludur. Genel kurulun sorumluluk davası açılması kararı almaması değil, ibra kararı alması esasen yönetim kurulunun sorumluluk davası açmasını engelleyici niteliktedir.

TTK'nın amacının sorumlu kişilerin yargı karşısına çıkarılması hususunda ETTK uygulamasında yaşanan tüm aksaklıkları gidermek ve bu amaç doğrultusunda eski uygulamadaki şekli ve maddi engelleri ortadan kaldırmak olduğu açıktır. Ancak TTK'nın birbiriyle ilgisiz bölümlerinde, sorumluluk kısmında yer alan TTK m. 555 hükmünde davayı şirketin açacağı; genel kurulda oyda imtiyazın geçerli olmadığı kararları düzenleyen TTK m. 479/3-c hükmünde ise genel kurulun sorumluluk davası açılması kararı alacağı düzenlemelerinin uygulamada karışıklığa yol açtığı da yadsınamaz bir gerçektir. Karışıklık ise yorum farklılıklarından kaynaklanmaktadır. Yargıtay'ın eski uygulamayı devam ettirmek şeklinde gösterdiği iradesinin de TTK'nın getirdiği yenilikleri anlamsız hale getirdiği ortadadır.

Doktrindeki görüşlerin farklılı̆ğ ve Yargıtay'ın doktrinde ortaya atılan ilk görüşü benimseyip eski uygulamasını aynen devam ettirmesi karşısında, yapılması gereken TTK'da bu hususa ilişkin net bir düzenlemenin getirilmesi ve durumun kanun hükmüyle açıklığa kavuşturulmasıdır.

Çözüm olarak değiş̧iklik önerilerimiz ise şu şekildedir:

TTK m. 555/ 1 hükmünün mevcut hali şu şekildedir:

"Şirketin uğradığı zararın tazminini, şirket ve her bir pay sahibi isteyebilir. Pay sahipleri tazminatın ancak şirkete ödenmesini isteyebilirler.”

\section{Değişiklik önerisi:}

"Şirketin uğradığı zararın tazminini, şirket ve her bir pay sahibi isteyebilir. Şirketin talebi, yönetim kurulu veya genel kurul kararına dayanabilir. Pay sahipleri tazminatın ancak şirkete ödenmesini isteyebilirler."

Şeklinde hükme eklenecek olan "Şirketin talebi, yönetim kurulu veya genel kurul kararına dayanabilir." cümlesi doktrindeki tartışmaları ve Yargıtay’ın katı uygulamasinı sona erdirmeye yetecektir.

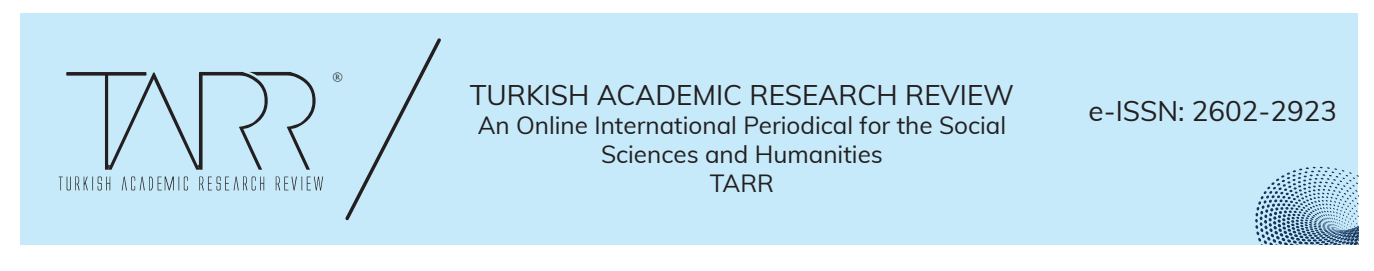




\section{Değişiklik önerisi:}

"Genel kurul da şirketin uğradığı zararın tazmini için sorumluluk davası açılması kararı alabilir. 479 uncu madde hükmü sakhdır."

şeklinde mevcut düzenlemeye yeni bir fikra eklenmesidir. Bu ek fikra, TTK m. 555 ve 479 hükümleri arasında bağlantıyı da sağlayacaktır. Ayrıca genel kurulun da yetkili olduğunu vurgulayarak, evleviyet gereği asli yetkinin yönetim kurulunda olduğunu ve organların bu konuda müşterek yetkisi bulunduğunu açıklığa kavuşturacaktır.

\section{Kaynakça}

Akdağ Güney, Necla. Anonim Şirket Yönetim Kurulu. İstanbul: Vedat Kitapçıllk, 2012.

Altaş, Soner. Şirketler Hukukuna İlişkin Yüksek Yargı Kararları. Güncellenmiş ve Genişletilmiş 2. Bası, Ankara: Seçkin Yayıncılık, 2018.

Altay, Sitkı Anlam. Anonim Ortaklıkta Yönetim Yetkilerinin Devrinin Sorumluluğa Etkileri. İstanbul: Vedat Kitapçılık, 2011.

Arslan, Ramazan/Yılmaz, Ejder/Taşpınar Ayvaz, Sema. Medeni Usul Hukuku. 3. Baskı, Ankara: Yetkin Yayınları, 2017.

Arslan, İbrahim/ Tüzemen Atik, Ebru. "Anonim Şirketlerde Yönetim Kurulu Aleyhine Sorumluluk Davası Açılması Kararı ve Açılacak Davada Şirketin Temsili”, Başkent Üniversitesi Hukuk Fakültesi Dergisi. C. 2, S. 2, 2016, s. 11-35.

Aşık, İbrahim, Medeni Usul Hukukunda Bekletici Sorun, Ankara: Seçkin Yayıncılık, 2012.

Bahtiyar, Mehmet. Ortaklkklar Hukuku. Güncellenmiş 12. Bası, İstanbul: Beta, 2017. (Ortakliklar Hukuku).

Bahtiyar, Mehmet. "Türk Ticaret Kanun Tasarısının Dili ve Bazı Hükümlerinin Değerlendirilmesi”, TBB Dergisi. S. 61, 2005, s. 47-106 (Ayrıca bkz. Makaleler. Cilt II. İstanbul, 2008) (Değerlendirme).

Bahtiyar, Mehmet. "Anonim Şirket Adına Yönetim Kurulu Üyelerine Karşı Açılacak Sorumluluk Davasında Genel Kurul Kararının Gerekli Olup Olmadığı Sorunu”, Prof. Dr. Seza Reisoğlu Armağanı. Ankara: Bankacılık Enstitü Yayınları, 2016 s. 393414 (Armağan).

Bilgili, Fatih/ Demirkapı, Ertan. Şirketler Hukuku. 9. Baskı, Bursa: Dora, 2013.

Bora, Sevda. Şirkete Borçlanma Yasağı. Ankara: Seçkin Yayıncılık, 2017.

Cahn, Andreas/Donald, David C. . Comparative Company Law. Newyork: Cambridge University Press, 2010.

Çamoğlu, Ersin. Anonim Ortaklk Yönetim Kurulu Üyelerinin Hukuki Sorumluluğu. Güncelleştirilmiş ve Genişletilmiş Üçüncü Bası, İstanbul: Vedat Kitapçılık, 2010.

Görgün, Şanal. Medeni Usul Hukuku. 3. Bası, Ankara: Yetkin Yayınları, 2014.

Helvacı, Mehmet. "Anonim Ortaklıkta Ticaret Kanunundan Kaynaklanan Azınlık Haklarının Hukuki Niteliği ve Tanımı”, Prof. Dr. Oğuz İmregün'e Armağan. İstanbul, 1998, s. 297-310 (Armağan).

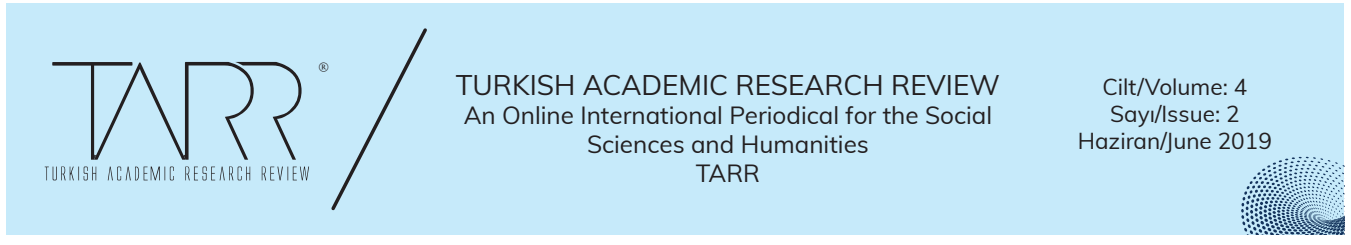


Helvacı, Mehmet. "Anonim Ortaklık Tarafından Yönetim Kurulu Üyelerine Karşı Açılacak Sorumluluk Davalarında Genel Kurul Kararının Gerekli Olup Olmadığ Sorunu -Düşünceler ve Değerlendirmeler-”, Yürürlüğünün 5. Yilında ve Yargıtay Kararları Işı̆ı̆nda Türk Ticaret Kanunu Sempozyumu (20 Ekim 2017). İstanbul: On iki Levha Yayıncilık, 2018, s. 143-175 (Sempozyum I).

Helvacı, Mehmet. "Anonim Ortaklık Yönetim Kurulu Üyelerinin Hukuki Sorumluluk Sistemindeki Başlica Yenilikler ", Türk Ticaret Kaпununun 5. Yıl Sempozyumu. 810 Kasım 2017, Ankara: Türkiye Adalet Akademisi, 2018, s. 335-357 (Sempozyum II).

Karahan, Sami (Ed.). Şirketler Hukuku. Konya: Mimoza Yayıncılık, 2012.

Kendigelen, Abuzer. Türk Ticaret Kanunu Değişiklikler, Yenilikler ve İlk Tespitler. Güncellenmiş 2. Basıdan 3. (Tipk1) Bası, İstanbul: On İki Levha Yayıncılık, 2016.

Kırca, İsmail/ Şehirali Çelik, Feyzan Hayal/ Manavgat, Çağlar. Anonim Şirketler Hukuku. C. I, Ankara: Banka ve Ticaret Hukuku Araştırma Enstitüsü (T. İş Bankası A. Ş. Vakfi), 2013.

Kortunay, Ayhan. 6102 Saynl Türk Ticaret Kanununa Göre Anonim Şirketlerde Yönetim Kurulu ve Üyelerin Bilgi Edinme Hakkı. İstanbul: On İki Levha Yayınc1lık, 2015.

Köksal, Aytaç, "Türk Ticaret Kanunu Tasarısının 309 ila 406 Maddeleri Arasında Düzenlenen Denetçinin Anonim Ortaklığın Bir Organı Olup Olmadığı Sorunu”, Prof. Dr. Firat Öztan'a Armağan, Ankara, 2010, s. 1387-1419.

Moroğlu, Erdoğan. "Anonim Ortaklıkta Azınlık Paysahiplerinin Korunması ve Haklı Nedenle Fesih”, Ord. Prof. Dr. Halil Arslanlinın Anısına Armağan. İstanbul, 1978, s. 463-477 (Armağan).

Moroğlu, Erdoğan. 6102 sayıl Türk Ticaret Kanunu Değerlendirme ve Öneriler. 7. Baskı, İstanbul: On İki Levha Yayınc1lık, 2012 (Değerlendirme ve Öneriler).

Moroğlu, Erdoğan. Türk Ticaret Kanunu'na Göre Anonim Ortaklıkta Genel Kurul Kararlarının Hükümsüzlü̈̆ü. Altıncı Baskı, İstanbul: On İki Levha Yayıncılık, 2012 (Hükümsüzlük).

Odman Boztosun, N. Ayşe. "Yeni Türk Ticaret Kanunu'nda Denetçinin Sorumluluğu, Alman Sistemi Mi, İsviçre Sistemi Mi?”, Arslanh Bilim Arşivi. s. 1-8, http: // arslanlibilimarsivi. com

Pekcanitez, Hakan/ Atalay, Oğuz/ Özekes, Muhammet. Medeni Usul Hukuku. 7035, 7101 ve 7145 Sayılı Kanunlarla Yapılan Değişiklikler Nazara Alınarak Gözden Geçirilmiş 6. Bası, İstanbul: Vedat Kitapçılık, 2018.

Poroy, Reha/ Tekinalp, Ünal/ Çamoğlu, Ersin. Ortakliklar ve Kooperatif Hukuku. Güncelleştirilmiş 12. Bası, İstanbul: Vedat Kitapçılık, 2010 (Ortaklıklar ve Kooperatif Hukuku).

Poroy, Reha/ Tekinalp, Ünal/ Çamoğlu, Ersin. Ortaklkklar Hukuku I. Yeniden yazılmış 13. Bası, İstanbul: Vedat Kitapçılık, 2014 (Ortaklıklar Hukuku I).

Poroy, Reha/ Tekinalp, Ünal/ Çamoğlu, Ersin. Ortaklıklar Hukuku II. Yeniden Yazılmış 13. Bası, İstanbul: Vedat Kitapçılık, 2017 (Ortaklkklar Hukuku II).

Pulaşlı, Hasan. Şirketler Hukuku Genel Esaslar. Gözden Geçirilmiş, 6728 Sayılı Kanunla Getirilen Yenilikler ve Yapılan Değişiklikler İşlenmiş, Güncellenmiş ve Genişletilmiş 5. Bask1, Ankara: Adalet Yayınevi, 2017 (Genel Esaslar).

Pulaşlı, Hasan. Şirketler Hukuku Şerhi. Cilt II. Ankara: Adalet Yayınevi, 2011 (Şerh).

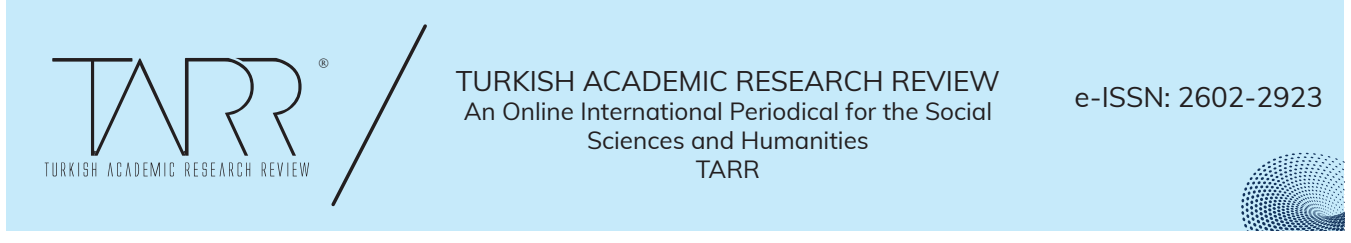


Şener, Oruç Hami. Ortaklıklar Hukuku. Gözden Geçirilmiş 2. Bası, Ankara: Seçkin Yayıncilik, 2015.

Tekinalp, Ünal. Sermaye Ortaklıklarının Yeni Hukuku. Değişiklikler ve İkincil Düzenlemelerle Güncelleştirilmiş 4. Bası, İstanbul: Vedat Kitapçılık, 2015.

Üçışı, Güzin/ Çelik, Aydın. Anonim Ortaklıklar Hukuku. C. 1, Ankara: Adalet Yayınları, 2013.

Yanlı, Veliye/ Akın, Murat Yusuf. Yeni Türk Ticaret Kanunu Dünya Değişiyor. Ya Siz? 2. Baskı, İstanbul: KPMG, 2012.

Yasaman, Hamdi. "Yönetim Kurulu Üyelerine Karşı Açllabilecek Sorumluluk Davaları", Prof. Dr. Oğuz İmregün'e Saygı Sempozyumu (Galatasaray Üniversitesi Hukuk Fakültesi Dergisi). 2013/2, s. 97-112.

Yıldırım, Ali Haydar. Türk Ticaret Kanunu Tasarısı'na Göre Limited Ortaklık Müdürünün Hukuki Durumu. İzmir: Güncel Hukuk Yayınları, 2008.

Yıldız, Şükrü. "Limited Ortaklıklarda Müdürlerin Sorumluluğu”, İstanbul Ticaret Üniversitesi Sosyal Bilimler Dergisi. C. 12, S. 24, 2013/2, s. 61-79.

Yördem, Yılmaz. Anonim Şirket Yönetim Kurulu Üyelerinin Hukuki Sorumluluğunda Farklılaştırılmış Teselsül İlkesi. Ankara: Seçkin Yayıncılık, 2017. 
